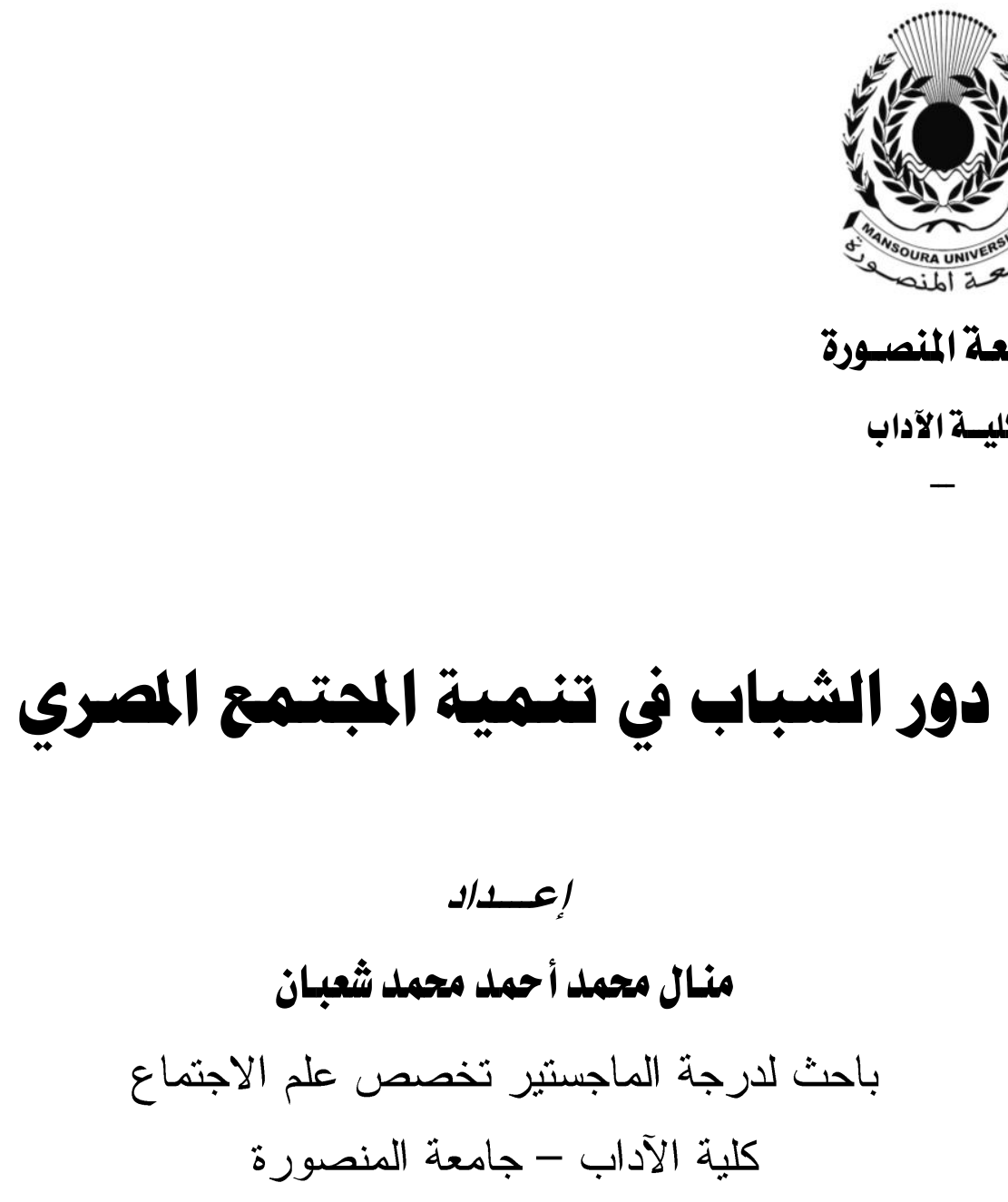

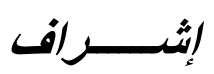

د. / إقبال مصطفى عبد الحكيم صادق

أ. دا مهلدي محمد القصاص

مدرس علم الاجتماع

أستاذ علم الاجتماع

وعميد المعهد العالي للخدمة الاجتماعية ببورسعيد كلية الآداب - جامعة المنصورة

كلية الآداب-جامعة المنصورة

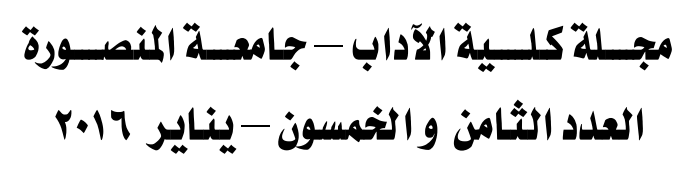




\section{دور الشباب في تنـمية المجتمع المصري}

\section{منال محمد أحمد محمد شعبان}

$$
\begin{aligned}
& \text { ملخص البعث: }
\end{aligned}
$$

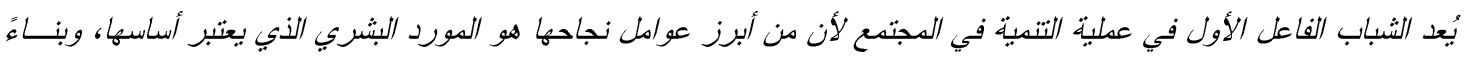

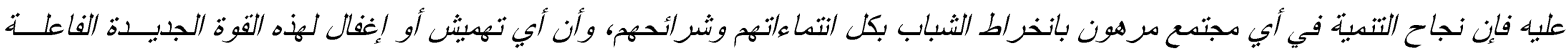

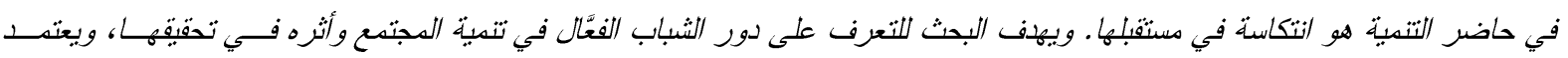

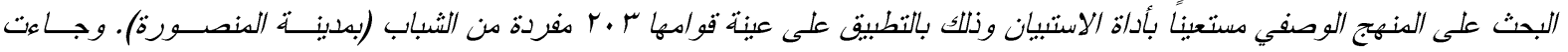

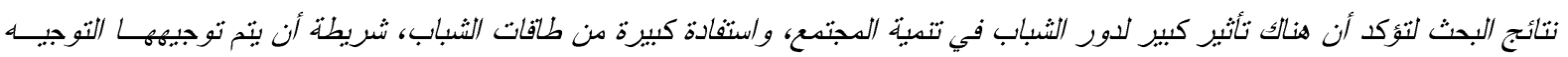

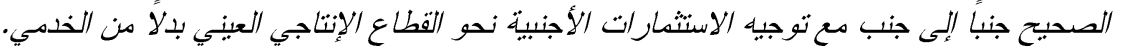

\section{Abstract}

Youth is the first actor in the process of development in the community that the main success factors is the human resource which is the basis, Accordingly the success of the development of any society depends on the involvement of youth of all backgrounds and segments, and that any omission or marginalization of these new power players in the present development is a setback in its future. The research aims to identify the effective role of youth in the development of society and its impact in their investigation, Researcher also depends on the descriptive analytical method using a tool the questionnaire and that application on a sample of 203 single youth (in Mansoura).The search results confirmed that there is a significant effect of the role of youth in community development, and take advantage of the large youth energies, provided that proper guidance is routed along with the foreign investments directed towards the productive sector rather than in-kind service.

سياسية، كان الثباب المحرك الأول لها كةــوة

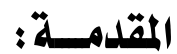

جديدة فاعلة ومؤثرة في الخريطة السياسية على

ممارسات الحكومات، فإن تللك القوة تســتدعي

التفكير في ضرورة إثر الك الثباب في عمليــة التنمية و النهوض بالوطن ومكانته.

إن إبراز خصوصية العلاقة بين موقــع

الشباب ودوره في التتمية تبرز من أهمية تأهيل

الثابة في شتى المجــالات، و إذكـــاء الشـــور

بالانتماء الوطني، ومن ثم التمكين في إدماجهم في مسار ات التنمية الثاملة، كما أن أسس إعداد الشباب ومشاركتهم في تتمية المجتمع تثمثل في تشجيعهم و إعطائهم الفرصة في التعبيــر عــن تطلعاتهم و آر ائهم مع أهمية زيادة انفتاح قيادات

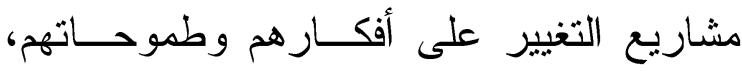
و الدفع بهم نحو القيام بمبادر ات تنموية فاعلة مع التأكيد على ضرورة إدمــاجهم فــي مشــاريع التنمية و الإصلاح إلى جانــب رفــع مســتوى
يقف الشباب إلــى جانــب مؤسســات

المجتمع التي تضع تتمية المجتمع نصب أعينها، مقدمةً تعهدها و التز امها توفير الأمسـن و التتميــة الاقتصادية وتقلبص نسب البطالة و الحــد مـنـ

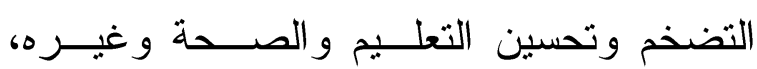

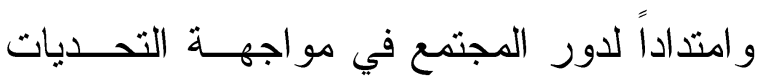
و الأزمات، بل قد يكون في بعض الأحيان دوره

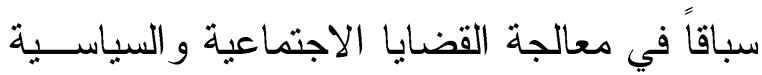

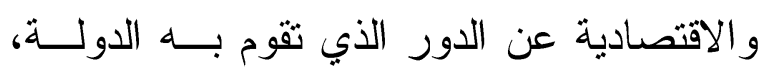
وليس تكميلي.

ويُعد الثباب الفاعل الأول فــي عمليــة التتمية في المجتمع لأن من أبرز عو امل نجاحها

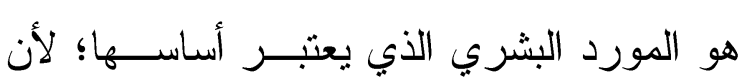
الشباب يشكلون الشريحة الأكبر في المجتمــع ومحركه الأسـاسي، ومع ما تشــــهـ مجتمعاتتـــا

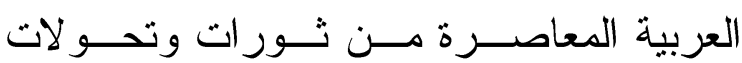


متعددة، ويمكن أن نميز لكل وضع مثلما تحــدد

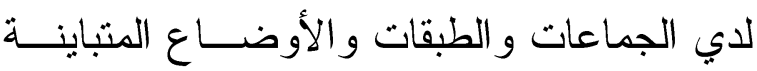
أنواعاً متتوعة من التوقعات تُحدد كيف يــؤدي الفاعلون سلوكهم بطريقة مميزة، وهكذا يتكــون التنظيم الاجتماعي من أنواع متعددة من شبكات

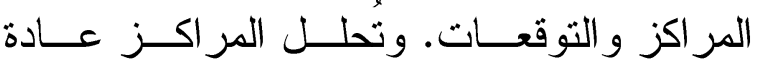
باستخدام مفهومات توضح كيف تتـــاخل هــــه المر اكز سوياً، لتُشكل أنماطاً مختلفة في إطـار

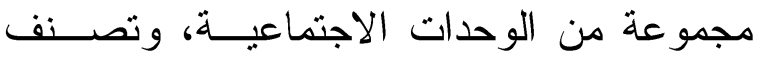
شبكات المر اكز إلى أثنكال في إطار مجموعــة الجئه

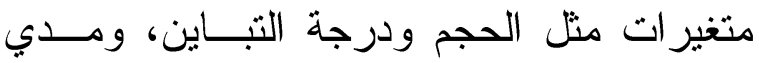
تداخل وتعقد العلاقات المتبادلة، ونتز اوح هـــــ الأشكال إبتداء من أنماط الجماعـات المتتوعـــة

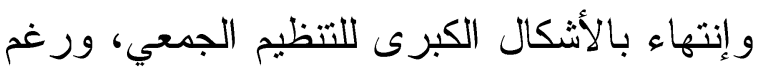

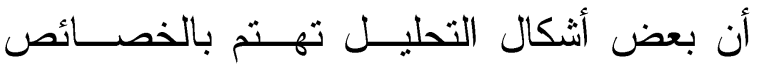
الرسمية لهذه المر اكز ، فمن النادر أن تحلل شبكة بالنة

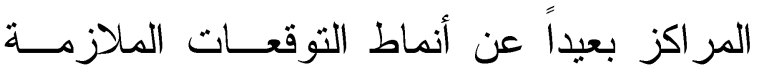

و المصاحبة لها (').

ويرتبط الأفر اد معــاً بســبـ الاعتمـــاد

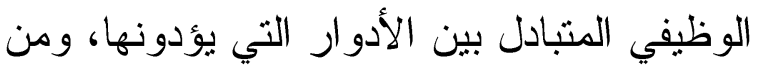

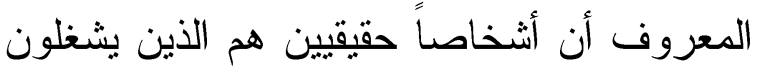
الأدو ار، و أنه ليس هنالك شخصان متماثلان تماماً

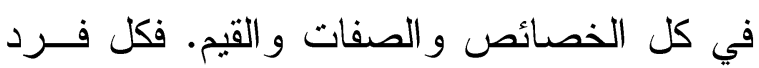

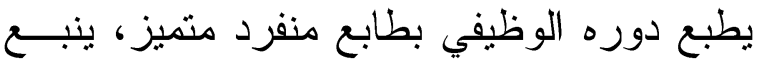

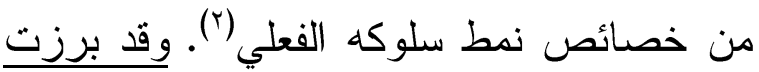
ثلاثة تصور ات أساسية للاور تمثلت فيما يلي: الأدو ار المفروضة الملزمة، يصـاحب إضــفاء التأكيد على توقعات الأفراد الذين يشغلون مر اكز الذران

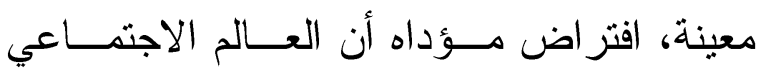

مشاركتهم في قبادة تلك المشاريع والإثــراف على تتفيذها، و العمل على اســتبعاد نظريــات الإقصاء و التهميش لهــم، وتعزيـز اســتقلالية

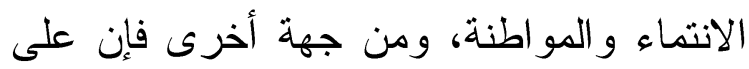
الثباب هم أنفسهم أن يبــادروا فـــي إطــلاق

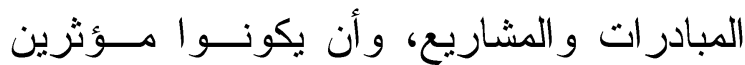
وفاعلين في المجتمع، ومشاركين في المشاريع التتموية المختلفة، وبناءً على ماسبق فإن نجاح التتمية في أي مجتمع مرهون بانخر اط الثباب

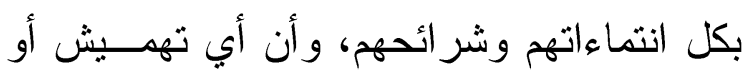

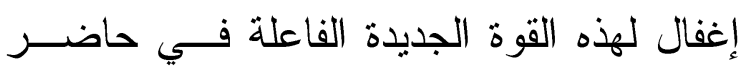
التمية هو انتكاسة في مستقبلها.

أهداف البحث

1. التعرف على دور الثباب الفعَّال في تتمية المجتمع وأثره في تحقيقها. r. الكثف عن المحددات الأساسية للتنمية في المجتمع. r. إلقاء الضوء على الرؤية المستقبلية لدور الثباب ومدى قيامه بواجباته تجاه

$$
\text { مجتمعه. }
$$

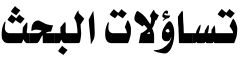
يتمثل التساؤل الرئيس اللبحث فيما يلي:

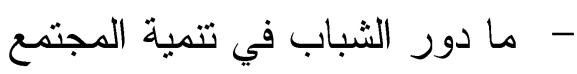

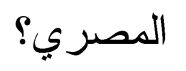

\section{الإطار المنهجي للبحث}

يعتمد البحث على نظريتي الدور ورأس

المال البشري، حيث برى منظــرو الــدور أن العالم الاجتماعي شبكة من الأوضاع أو المراكز لئزي

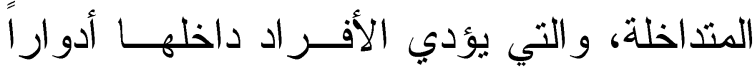


سياساتها المتعلقة بالموارد البشرية حيث أثارت نظرية الاستثمار البشري لشولتز اهتمـام عـدد كبير من الباحثين الاقتصاديين لمعرفة إمكانيــة تطبيق هذه النظرية في بعض مجالات الاستثمار

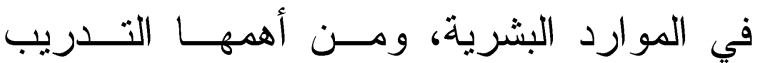
و التكوين (£).

ويتضمن رأس المال البشري العناصــر التالية: المعرفة- القدرات- المهار ات- القـدرة على العمل، وتتضــــن هـــــه الأخيــرة الحالـــة الصحية والنفسية للفرد وتتأثر هذه العناصر بكل من: الرضا الـــــيفي - الإلتــز ام - الحــافز الداخلي. ويحلل "مــايو Mayo " رأس الدــال البشري وفقاً لثلاث أبعاد هي: - القدر ات و الإمكانبات: و هذه تشمل مفاهيم مثل المسـتوى التعليمـي والمهــارات المهنية و الخبرة و المو اقف و الاتجاهــات

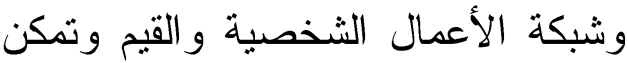
الموظفين الحاليين من التحــــك داخــل المنظمة. - المين

- الحافز و الإلتز اد: وهذه يشير إلى ربـط الموظفين مصالحهم بمصالح المنظمة. - الابتكار و التعلم: و هذه يبين درجة انفتاح الموظفين على التغيير . وقد حاول "شولتز" البحث عن تفسيرات أكثر فعالية لتفسير الزيادة في الاخل، فسعى إلى تحويل الانتباه من مجرد الاهتمــام بالمكونــات المادية لر أس المال إلى الاهتمام بتلك المكونــات التان

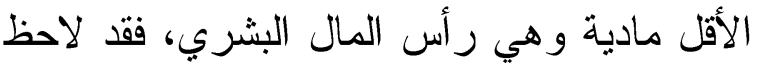

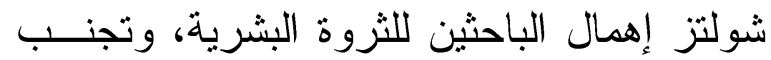

يتكون من مجمو عة قو اعد ملزمة و اضحة نسبياً، ومن ثم ينظر إلى ذات الفرد ومهــار ات لعـبـ

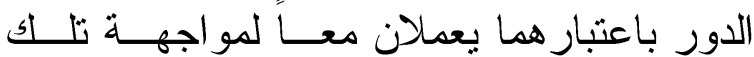
القو اعد الملزمة. الأدوار الذاتية، ولما كانت الذات مثل المنثـــور في علم الطبيعة توصل كل التوقعات، فإن هـــه التوقعات تخضع لتفسيرات الأفر اد الذين يشغلون المر اكز، و عندما تؤكد المفهومات على إدراكات

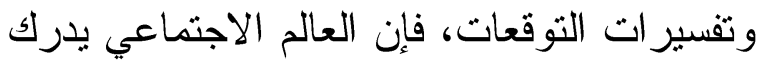
باعتباره مكوناً من إطار المقاييس الذاتية للأفر اد في مو اقف التفاعل.

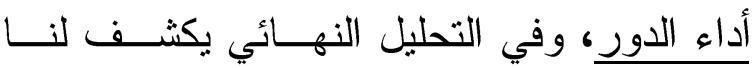
السلوك عن التوقعات و المقاييس الذاتيــة التــي يقيس بها الأفر اد هذه التوقعات، و عندما تعطيـي

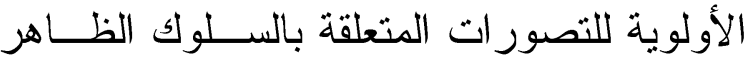
يدرك العالم الاجتماعي باعتباره شبكة من أنماط لاطهورك

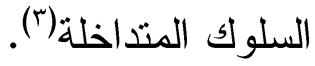
أما نظرية رأس المال البشري فإنها تقوم على فرضية أساسية مفادها وجــود اختلافــات جوهرية بين الأفر اد، فيما يتعلق بكمية الاستثمار

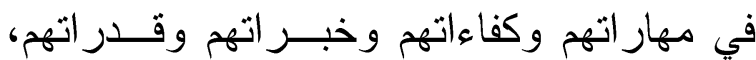
وينحر عن هذا التمايز ضرورة وضع المنظهـة لمجموعة من الاستر اتيجيات و السياسات للتعامل

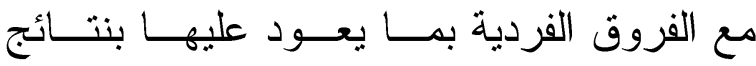
اقتصادية مجدية، ووفقاً لهذه النظرية يعتبر الفرد

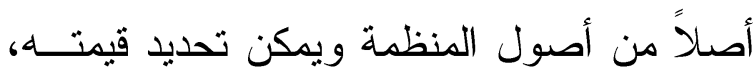
ويهدف المفهوم إلى زيــادة القيمــة الر أســمالية

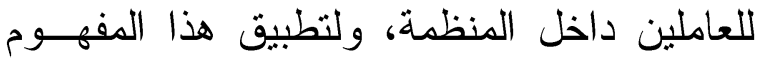

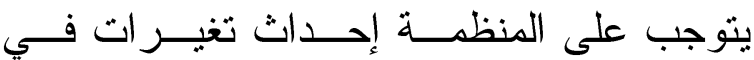


بالتدريب ونقل المهار ات من أجل الإسراع فــي معدل الاستثمار ات و النمو الاقتصادي على أسس السن الإسل تتموية سليمة، ويتبع البحث المـنـهج الوصــفي مستعيناً بأداة الاستبيان وذلك بالتطبيق على عينة

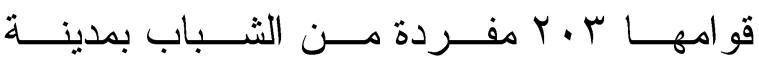

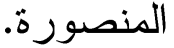

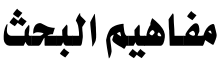
-

يُمتل الثباب في المجتمع فئة عُمريــة، تتسم بعدد من الصفات و القــدر ات الاجتماعيــة و النفسية المتميزة، وتختلف بدايــة هــــه الفئــة العُرية ونهايتها باختلاف الأوضاع الاجتماعية و الاقتصادية و الثقافية السائدة في المجتمع. و هكذا يرفض هذا التصور الحتمبة البيولوجية، ويُحــدد مرحلة الثباب في ضوء عدد مــن الخصــائص

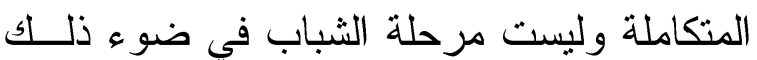
مرحلة منفصلة عن بقية مر احل العُمر، وخاصةً مرحلة الطفولة و المر اهقة و إنما هي امتداد لهــــه

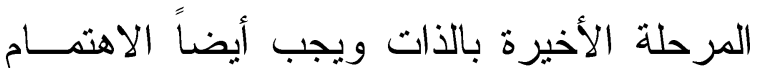

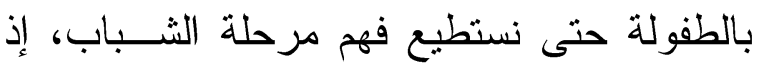
لابد من تو افر النظام الاقتصادي الاجتماعي الذي يهيئ السبيل للانتقال إلى مرحلة الثباب، التـي لإني

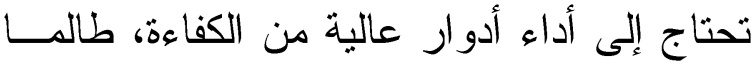

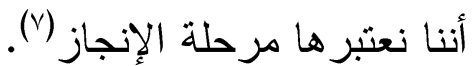
و الثــباب مــن وجهــة نظـــر علمــــاء الاجتماعي هم الفئة التي اســتوعبت مجموعــة

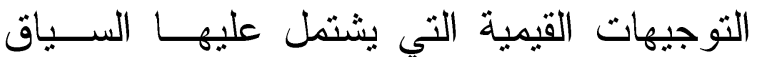
الاجتماعي من خلال عملية التشئئة الاجتماعيـة

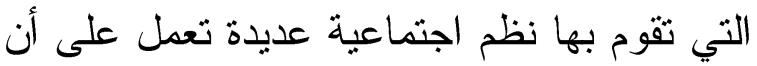

أي تحليل منظم لهذه الثروة، لذا فقد ركز اهتمامه للوصول إلى نظرية الاستثمار في رأس الهــال البشري تهدف إلى تحقيق التنمية الاقتصــادية. ومفهوم شولتز للإستثمار في رأس المال البشري

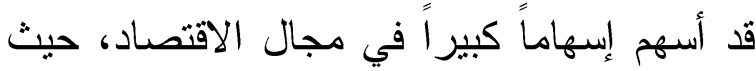
أثشار إلى ضرورة اعتبار مهار ات ومعرفة الفرد شكل من أشكال رأس المال الذي يمكن الاستثمار فيه، فمن وجهة نظر شولتز فإن هذا النوع مــن

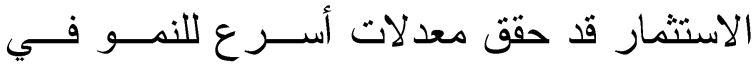

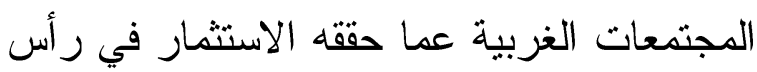
المال المادي، ولذلك فنمو رأس المال البشــري يمكن أن يكون من أهم السمات المميزة للنظــام الاقتصادي(0) ومما سبق يتضح أن رأس المال البشري هو العلامة الفارقة والهامة في المجتمع، حيــث لـثن

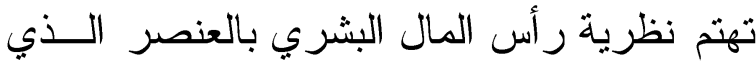

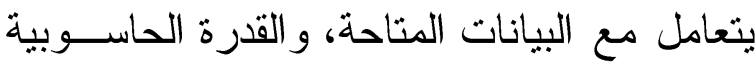

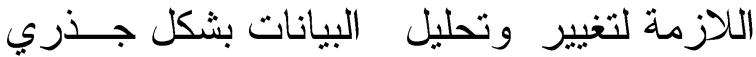

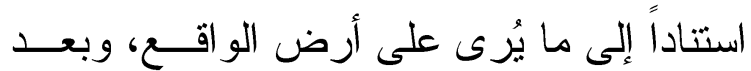

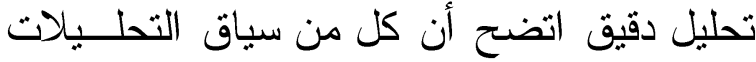
و البيانات و التقارير الخاصة، توفر الأثر الحقيقي وتساعد على الاستثمار الأمثل، وهذا هو الهدف الأكثر أهمية في تحليل رأس المال البشري("). ومن هنا نجد أن نظريتي الــدور ورأس رئس المال البشري من النظريــات الأكثــر ملائمـــة لدر اسة دور الثباب في تتمية مجــتمعهم، ولأن

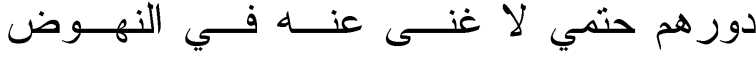
بالمجتمع، أوجب ذللك الاهتمام بهم كأهم عنصر

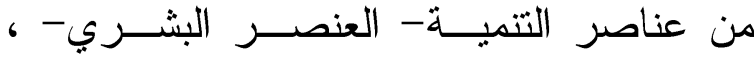


الموجودة بالفعل، و إعادة توجيههــا وتتشــبطها بطريقة جديدة، وتهيئة الظروف المتعددة، لهـذا

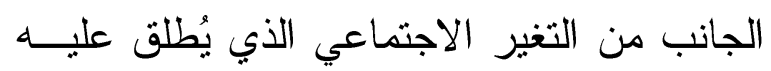

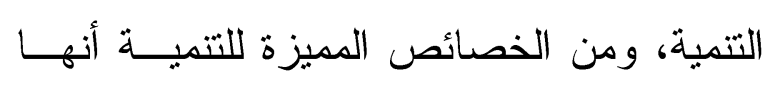
ليست عملية تطور تدريجي تلقائي حيث إنها تتم

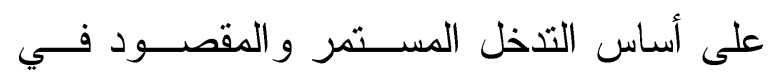
المجتعات، وتستمر عن طريق هيئات التتميــة التي تكون جزءاً من بناء الدولة (9).

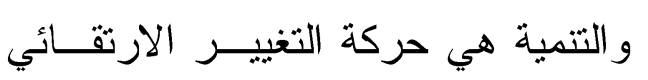

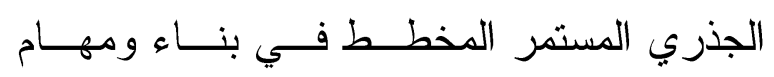

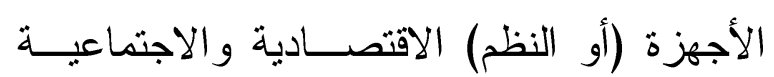

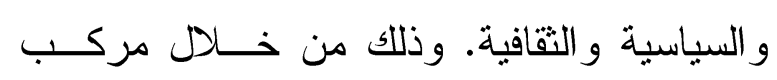

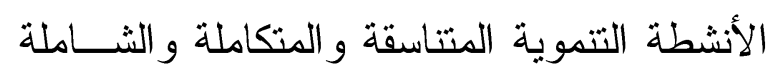

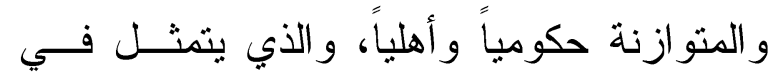

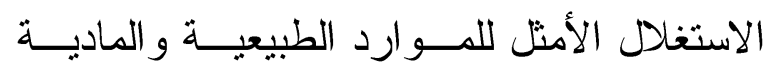

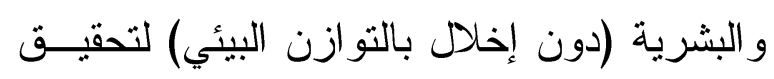
العدالة التوزيعية (و الجيلية) للمردودات التتموية التئية

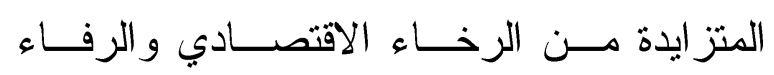

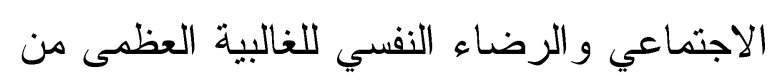
السكان(·) ويُقصد أيضاً بمفهوم التتمية انبثـاق النهاء ونمو كل الإمكانيات و الطاقة الكامنة في كيــان معين بشكل كامل وشامل ومتو ازن، سواء كــان هذا الكبان هو فرد أو جماعة أو مجتمع ولهـــا التعريف عناصر أساسية أهمها:

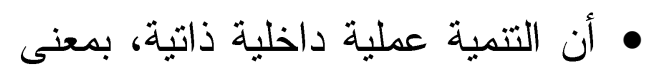

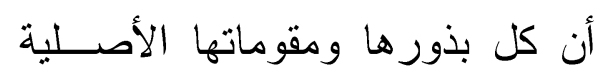

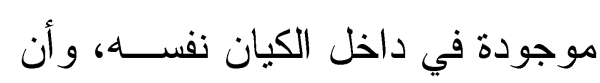
أي عوامل أو قوى خارج هذا الكيان
نو ائم بين التوجهات القيمية وبين إثباع الحاجات والاهتمامات الأساسية للشخصية في مسـتوياتها

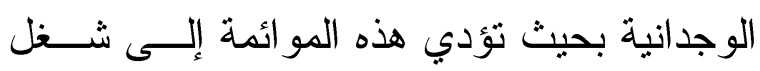
الثباب لمكانة اجتماعية معينة وتـأديتهم أدواراً

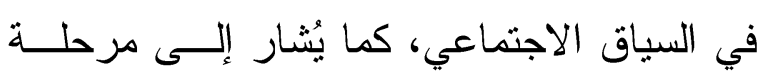

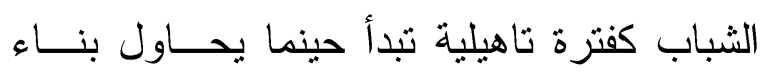

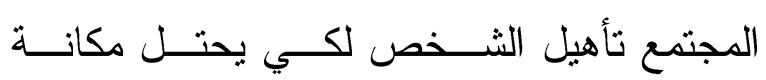

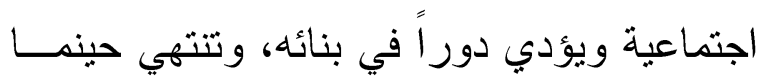

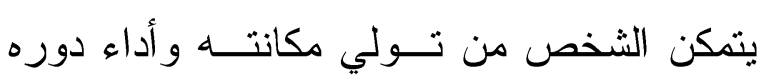
وبهذا يشكل الشباب فئة محددة تقع بين مرحلتين فاصلتين خلال فترة الحياة(^). التعريف الإجر ائي للشباب: مجمو عة من الأفراد

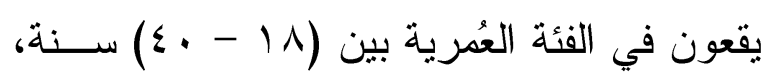
يحملون من الصفات الجسمانية و القدرات النفسية

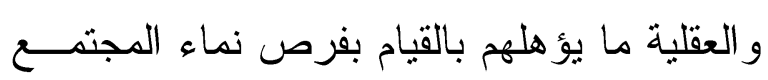

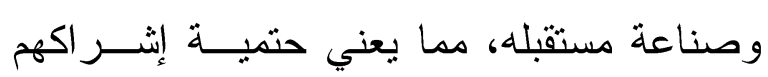

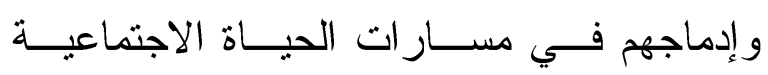

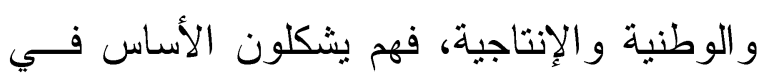

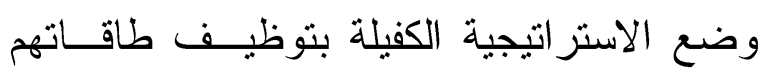

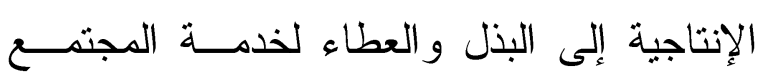
وتتميته. - التمية -

يُستخدم مصطلح التتمية دولياً على نطاق الفئ

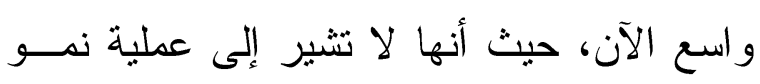

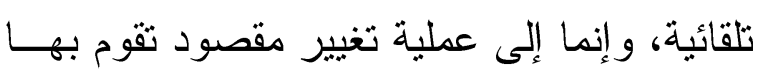

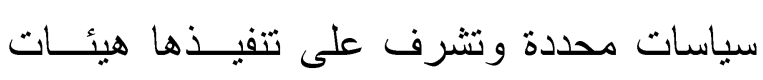

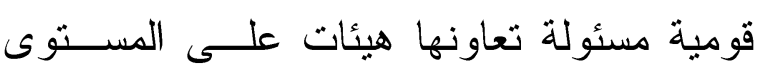

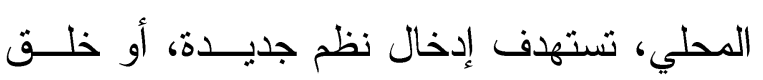

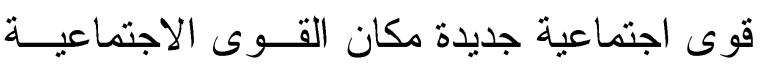


وفيما يلي نعرض لمحاور البحث، وتتمثل في: الشباب في المجتمع المصري، محددات التنمية في المجتمع المصري، الشباب والتنمية .. بين

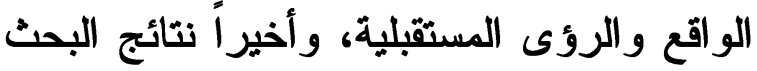

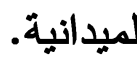

\section{أولاً : الشباب في المجتمع المصري ..}

يُمتثل الثباب الركن الحيوي في البنــاء

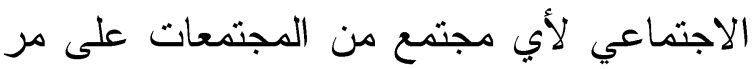

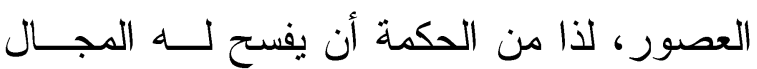

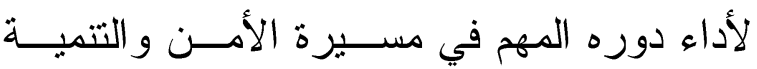

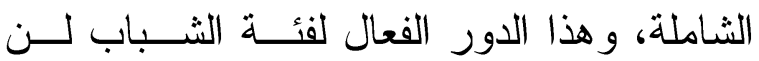

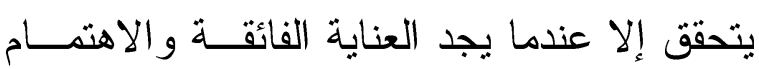
البالغ تجاه حل مشكلاته و همومه وقضاياه و إيجاد

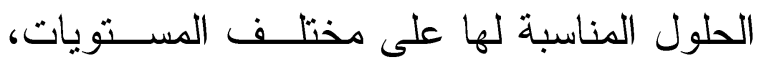
وتُعد مرحلة الثباب من أهم المر احل التي يمـر لهر

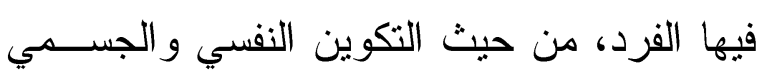

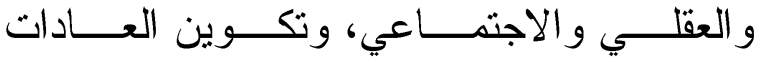

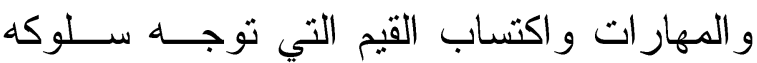

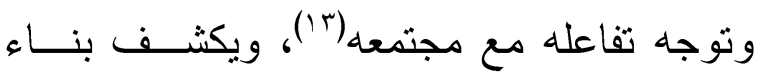
الشخصية الثابة عن تضمنها لأربعة مكونـات ولتهات

ويُعد المكون البيولوجي: هو المكون الأول فـي بناء الثخصية ويتضمن هذا المكون مجموعــة الثران الدو افع و الحاجات و الغر ائز ، وهي جو انب لهــــا وجودها القوي في شخصية الثباب، ومن ثم فإن

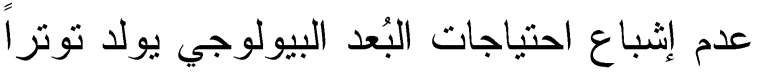
و اضطر اباً في بناء الثخصية.

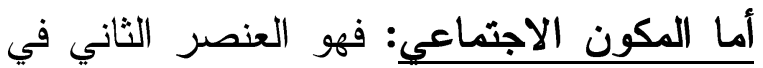
بناء الثخصية الثابة، حيث يسعى الثباب إلـى لهى
لا تعدو أن تكــون سـوى عوامــل مساعدة أو ثانوية.

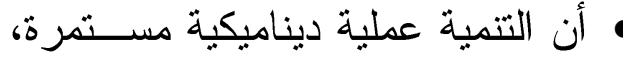
أي أنها ليست حالة ثابتة أو جامدة. • أن التتمية ليست ذات طريق و احد أو لو لئ اتجاه محدد مسبقاً، و إنما تتعدد طرقها و اتجاهاتها باختلاف الكيان وباختلاف وتتوع الإمكانيات الكامنة في داخــلـل كل كيان ('1). و التنمية عملية تحويل للوجود الاجتماعي للأفر اد عن طريق تملكهم لقدرات العيش الكريم بأبعـاده (الاقتصــادية و التعليميــة و الصــحية)

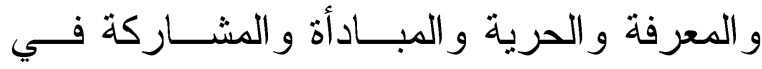
القرار ات المصيرية المتصلة بحياتهم، وتكثـف ولف هذه القدرات عن أن الوجود الاجتماعي للإنسان يتأسس على أبعاد مختلفة لا تتدرج على متصل التصن

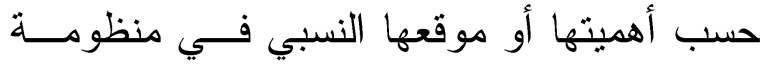
الحياة، ولكنها تتو ازى ويكتسب كل عنصر منها أهميته من أهمية الآخر (T). التعريف الإجرائي للتنمية: هي الانثقال بالمجتمع

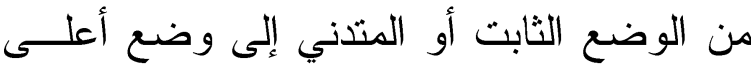

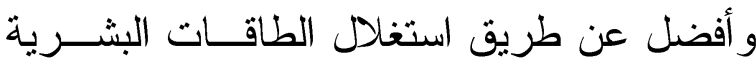

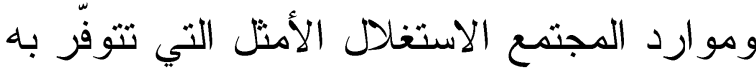
لزيادة الإنتاج، كما أنها عملية تطوير شَــامل أو لأل جزئي مستمر وتتخذ أشكالاً مختلفة تهدف إلـى لـى الرقي بالوضع الإنساني. فالتتمية عنصر أساسي

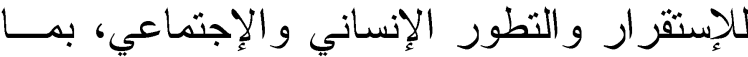

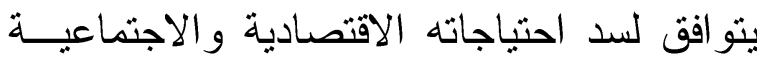

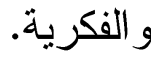


في النهاية إلى عدم اســتقرار بنــاء الثخصــية الشابة(10).

وتأتي أهمية مرحلة الثباب في أنها تمثل

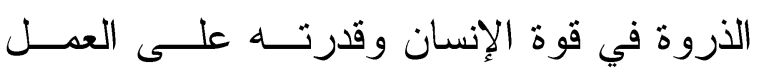
و العطاء، ويمكن تلخيص أهمية مرحلة الثــباب فئس الإنسان في النقاط التالية:

1- التمتع بالصحة والعافية: فمرحلة الثباب

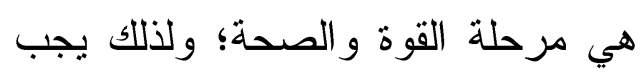
استثمار ها في شئ مفيد، في تأهيل نفسه وله وله

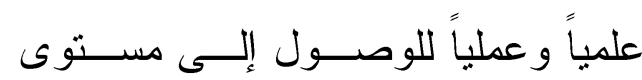
أعلى.

r- الذروة في النشاط و العمل: يعيش الثباب في هذه المرحلة في أوج قوته ونشاطاته

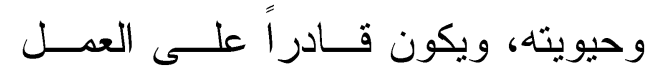
و الإنتاج و العطاء في أقصـى ولـى الحـدود

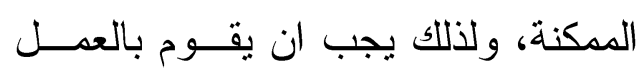

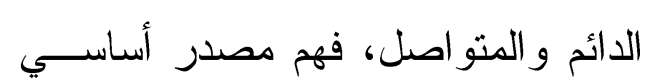
للتغير الاجتماعي.

r- القدرة على تحمل المسئوليات الكبيرة:

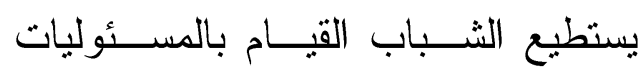

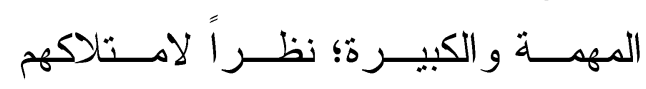

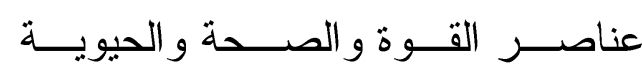
و الحماس والاندفاع نحو العمل، و إثبات الذات(')

ـ - يحتل الشباب قطاعاً أفقياً من القطاعات الرئيسية التي يتكون منها البناء السكاني

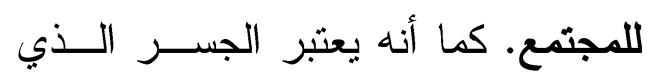

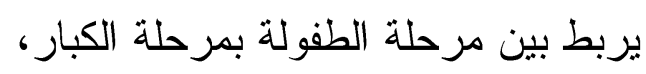

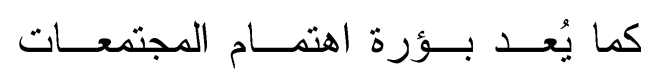

التفاعل مع الآخرين، و إذا كانت الثخصية الثشابة الثية

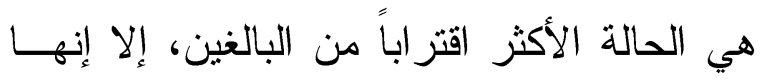

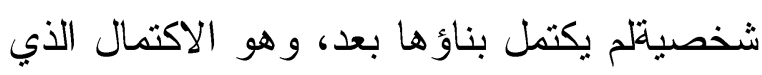

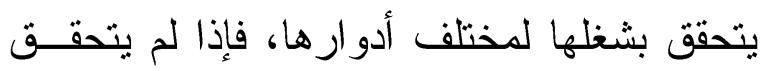

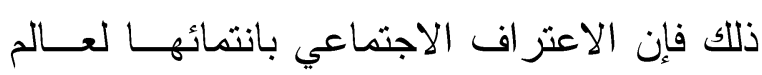

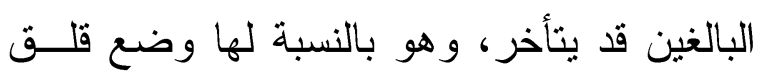
ومنونز (ع ال) ويشكل المكون السيكولوجي: المكون الثالث في بناء الثخصية الثابة، ولأن الثخصية الثابة لم الم الثيكون

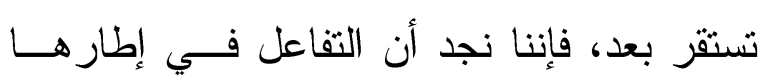

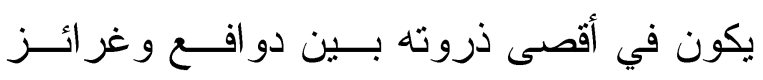
المكون البيولوجي وبين ضوابط المكون الثقافي

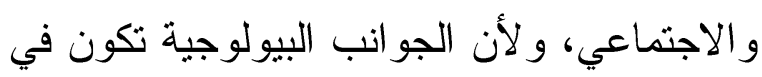

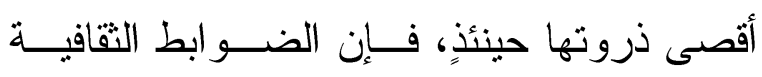
والاجتماعية تكون هي الأخرى الأكثر فعالية في

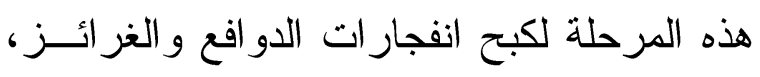

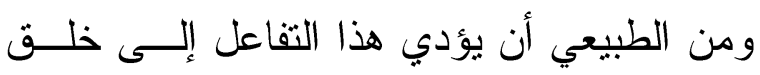

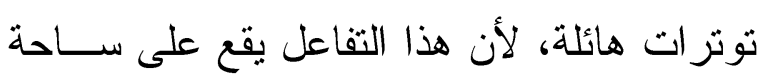
الشخصية الشابة. أما المكون الثقافي: المكون الرابع حيث تسنو عبة الثخصية الثابة مضامين هذا البعد "الدين و القيم و الأخلاق" من خلال عملية التنشئة الاجتماعيــة. ولأن التقافة تلعب دور ها في توجيه الســلوكيات

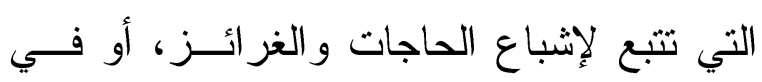
تحديد حقوق و التزامات الأدوار التـي تثــــاتها

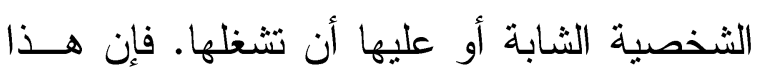

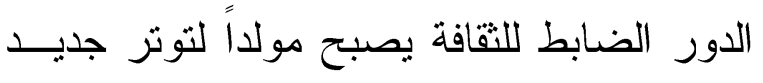

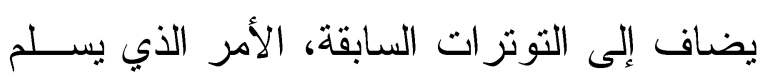


إلا عبئًا على الأنظمة الحاكمــة، حبــث تضيق ذرعا بهذه الكتلة المتز ايدة مسن

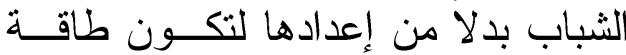
صناعة المستقبل.

- عدم تداول السُلطة وهو نتيجة طبيعية لما سبق فنجد السُّطة مصابة بالثــيخوخة، فالقيادات الحكومية تتز اوح أعمار هم من

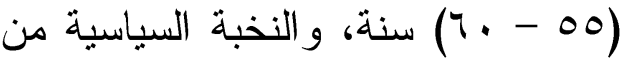

$$
\text { (^. - - 0.) }
$$

ويعيش الثباب المصري أزمة اغتراب حقيقي في مجتمعهم، وهذا الاغتر اب ناتج عـن

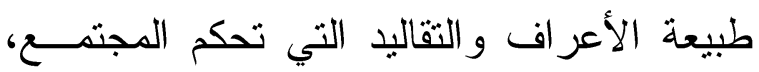
و عدم تطورها بما يتتاسب مع منطلبات الثباب، بخلاف عدم تطور ها لكي تتناسب مع مقتضيات العصر و التطورات المحيطة في العالم الخارجي، هذا بالإضـافة إلى التجاهل وعدم الاهتمام الـــي

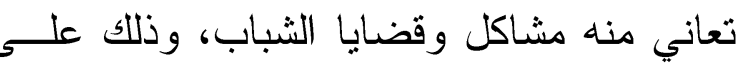
المستوى الرسمي وغير الرسمي، فجيل الثباب

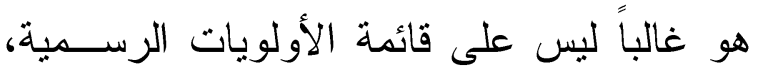

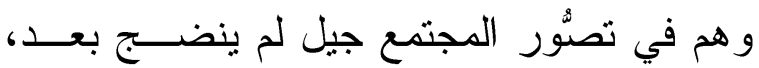

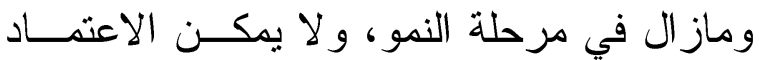
عليه، وقدرته على تحمل المسئولية تكاد تكـــن معدومة. ويرى علماء الاجتماع أن الثباب الذين يعانون من هذه الظروف يكون أمسـامهم ثلاثــة

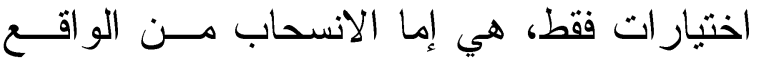
ورفضه وهو ما يُسمى بالاغتراب، أو الخضوع له في الوقت الذي ينفر منه، أو التمرُّد على هذا

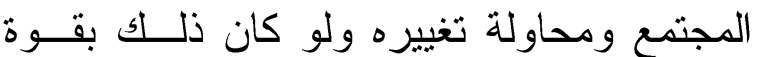

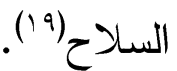

الإنسانية وذلك لما حباه الله من طاقـات

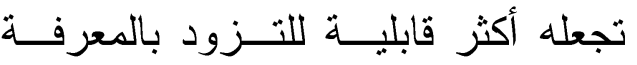

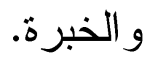
يُعد الشباب في المجتمع أكثر الفئات التي تتسم بأعلى درجات من النشاط و الحيوية: غيــر

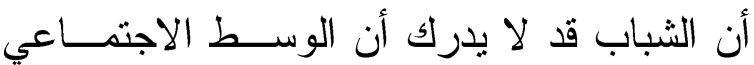

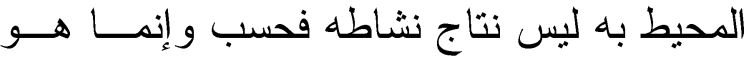
نتاج لنشطة قامت بها أجيال سابقة أيضاً، ولذلك ولك إنها

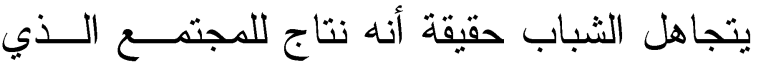
يعيش فيه، فتر اهم يميلون إلى تصوير نسق ثقافي

خاص بهم وهو ما يعبر عنه ثقافة المجتمع (IV). كما يُمتل الشباب قطاعاً كبير اً في البناء السكاني المصري، إذ تشكل الفئة العُمرية التــي لـي

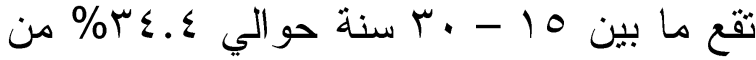
إجمالي عدد السكان، مما يشير إلـــى أن البنيـــة

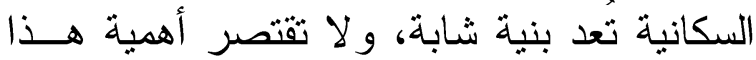

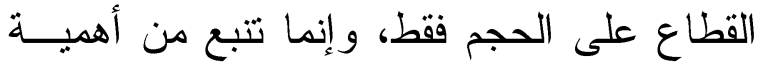

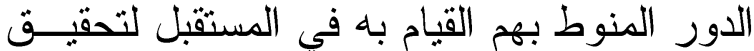
أهداف التتمية و النهوض بالمجتمع، فالثباب هو المحرك و الدينامو الخاص بالمجتمع يدفع به إلى بلى الأمام ويقود عملية التتمية والتغيير الاجتماعي،

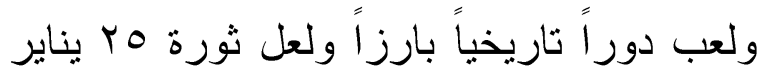

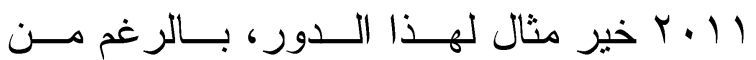
المشكلات التي يعانيها الثباب، منها على سبيل المثال لا الحصر (^) (1): - معاناة الثباب من ندرة الفرص و انعدام

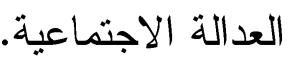
- - النظرة السلبية للنظام تجاه دور الثـــباب الناعه وفاعليته في تتمية المجتمع، و أنه لا يمثل 
الشريحة أن تكون منتجة بصورة فعالة، بمعنى لئل

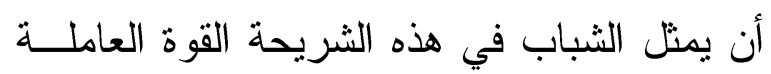

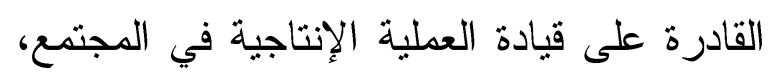

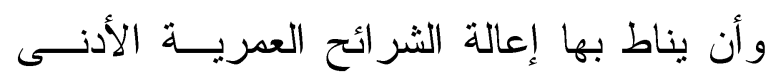
و الأعلى، و إذا كان قطاع الشباب يقع على عاتقه إنه

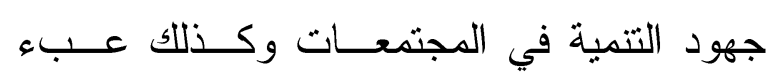
التحو لات السياسية والاجتماعية و الاقتصــادية،

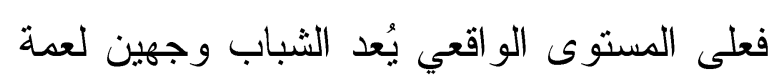

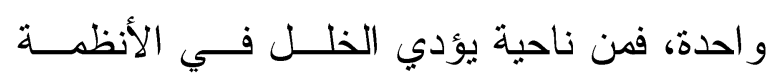

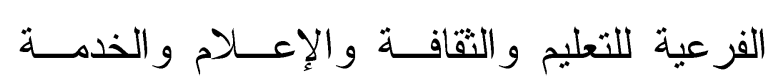

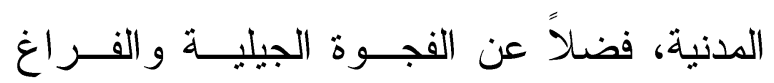
الفكري و السياسي إلى كون الثباب قوة اجتماعية

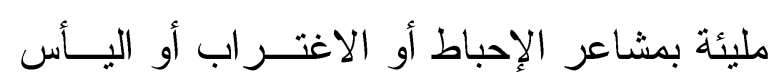

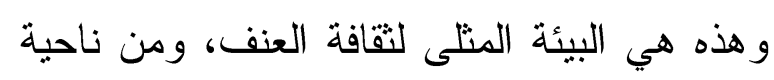

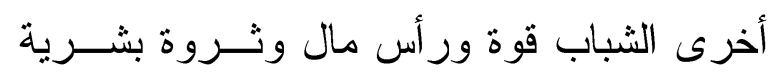
هائلة إذا أستثر بحكمه ووعي وتخطيط علىـي وني

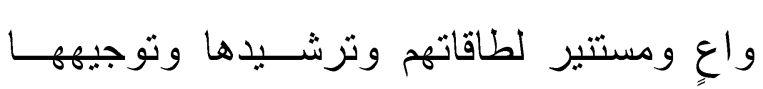
الاتجاه الصحيح، لتحقيق الأمل المعقود عليه في وني

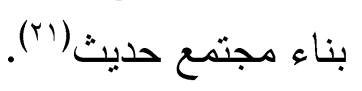

\section{ثانياً : محددات التنمية في المجتمع المصري}

يجد المتتبع لأيديولوجية التتمية خــالدل

عهد الرئيس "عبد الناصر" وبخاصة منذ منتصف لايدية لخدية

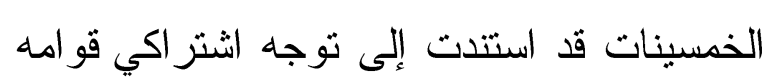

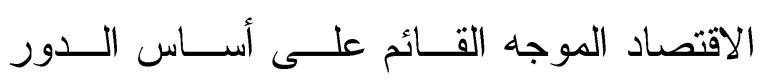

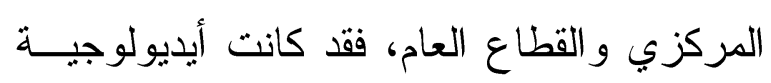

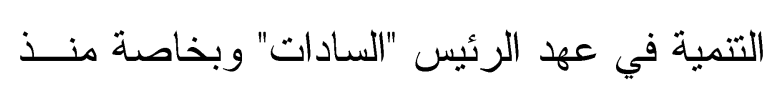
منتصف السبعينات على النقيض فقد استتدت إلى لى

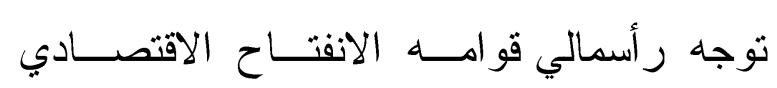

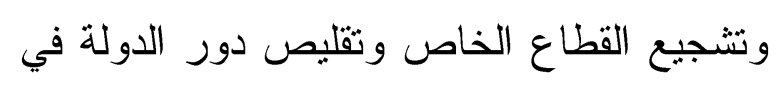

ومن أهم المشكلات التي تواجه الشباب

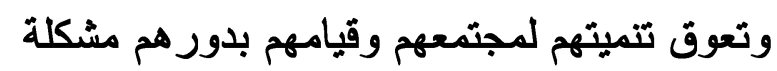

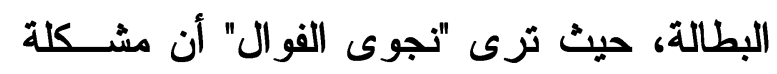

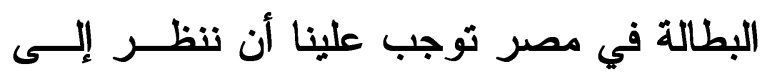

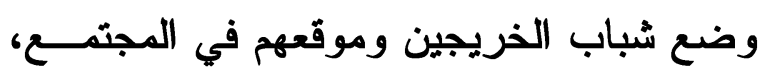

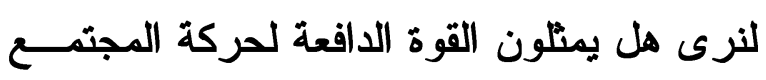

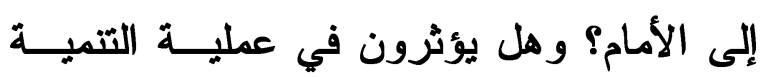

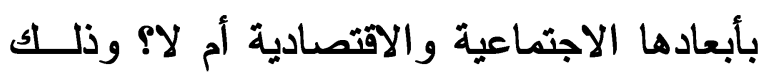

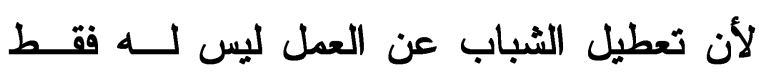
انعكاس اقتصادي، و إنما له أيضاً آثار عميقـــة

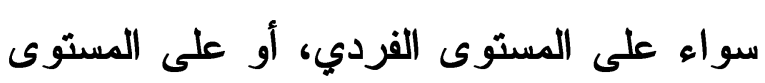

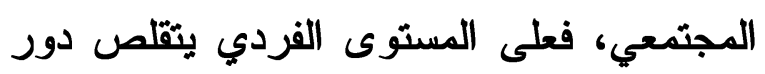

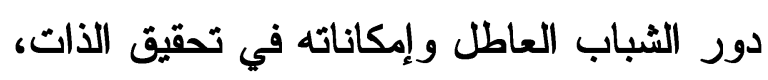
وفي شعور هبأن له قيمة إيجابية في المجتــع. والبطالة تعني -على مستوى المجتمع- خسارة

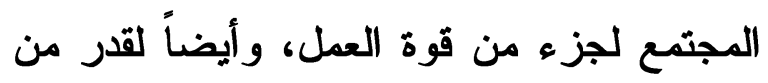

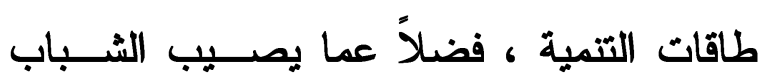
المتعطل من إحباط نفسي قد يدفعه إلى الإقـــدام

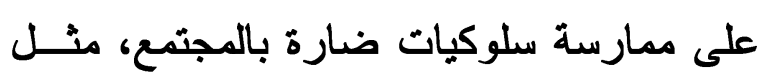
تعاطي و إدمان المخدرات، والتورط في ارنكاب

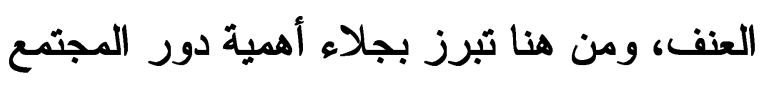
المدني إلى جانب جهد الدولة في توقي تأثيرات

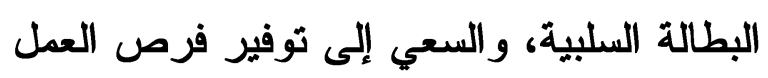

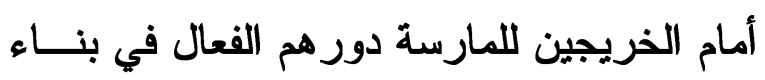

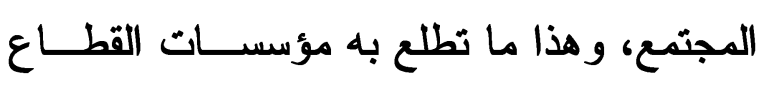
المدني في معظم الدول المنقدمة(·r). فالثباب هم عصب الأمة، وهم الثريحة

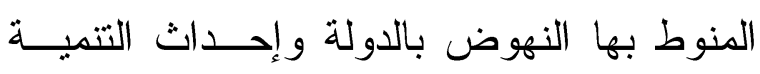

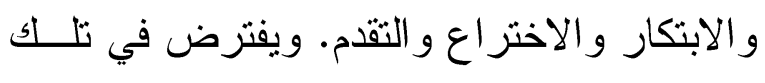


سرعان ما فشل في توليد فرص العمــل لقــوة عاملة كبيزة، بل وقضى على التصنيع(rr). وتعاني مصر من مشاكل مزمنة تتعلــق

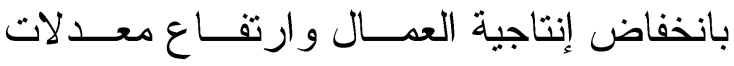
التضخم، وتمتد الجذور الأساسية لهــا لتشــمل لسياسات الأجور وتعويضــات العــاملين فـي الاقتصاد، في كل من القطاعين العام و الخاص. ونشير أن محاولة رفع الأجور لتتاسب مسـتوى الأسعار هو في صميم الجدل الدائر حول التآكل في الدخل الحقيقي مقارنة بتكاليف المعيشة، في حين أنه أمر هام لأهداف اجتماعية، حيــث أن تعديل الأجور إلى مستوى الأسعار دون زيــادة آله مماثلة في الإنتاجية، قد يكون لها آثار سلبية على له الاقتصاد، كما أن معالجة المخاوف بشأن ارتفاع تكاليف المعيشة ينبغي تقييمها بعناية عند تصميم سياسات الأجور نحو تحقيق العدالة الاجتماعيــة أكثر وزيادة كفاءة العمالة بعد ثورة مب يناير .في المقابل، يجب أن تتماشي زيادة الأجور و الحو افز مع الإنتاج، لخلق فرص عمل و التخفيــف مــن الضغوط التضخمية، مما يؤدي إلى رفع مستوى المعيشة وتحسين رفاه العمال(عَr). هنالك تاريخ طويل من "المشاركة" فــي التتمية، و على مدى و اسع حاولت مجمو عة مــن وكالات التتمية الوطنية و الدولية على حد ســـو اء

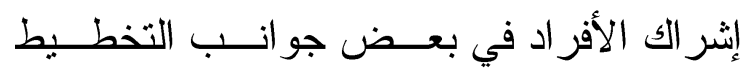
و التنفيذ. فمصطلح "المشاركة الشعبية" الآن جزء من الإسلوب القياسي للعديد من وكالات التتمية، بما في ذللك المنظمات غير الحكومية و الــدو ائر

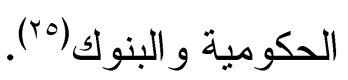

الاقتصاد و المجتمع، فإن أيديولوجية التتمية فـي عهد الرئيس الأسبق "مبارك" تمثلت في محاولة التوليف بين الأبديولوجيتين اللتين سادتا خــلال عهدي سلفيه، خاصة و أن كلاً منهما قد سعى إلى تغيير المجتمع المصــري سياســياً واجتماعيـاً و اقتصاديا، ولم يترتب على هذا التوجه التنموي أي نتائج اقتصادية إيجابية، بـلـل إن الأوضـــاع

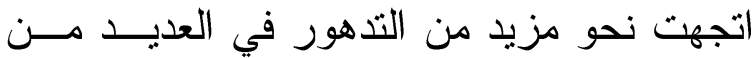
القطاعات، وبقيت الأزمــة الاقتصـــادية حـــادة

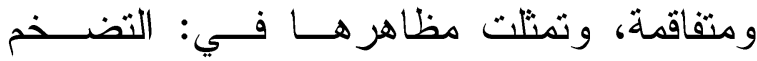
و البطالة وتدني معدل النمو وعدم التوازن فـي خطط وبر امج التنمية، وعجز في الموازنة العامة و التبعية الاقتصادية للخارج(rr). وفي ظل سياسة الباب المفتــوح أخـــ القطاع الخاص دورًا أكبر في الاستثمار ات، ونم توسيع الإقر اض الرخيص نسبياً لرجال الأعمال. ومع ذلك فقد تركزت أغلب استثمار ات القطــاع الخاص في نشاطات غير إنتاجية، مثل البنايــات الفاخرة و المضاربة في العقار ات و استير اد السلع الكمالية، بل ونجح بعض رجال الأعمــال فـي تحويل جزء مــن القــروض إلــى حســاباتهم الشخصية خارج مصــر، وتحــول الاقتصـــاد المصري إلى اقتصاد ريعي يعتمد على مصادر

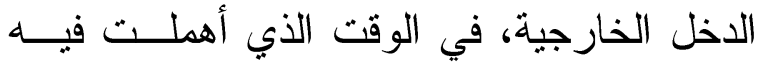
قطاعاتهـــا الإنتاجيـــة، الزر اعـــة و الصـــــاعة، فإجراءات التحرير الاقتصادي لم توجــهـ نحــو

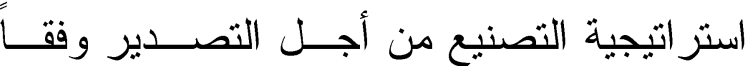
لنموذج شرق آسيا، و إنما إلى اقتصـــاد مفتـوح 


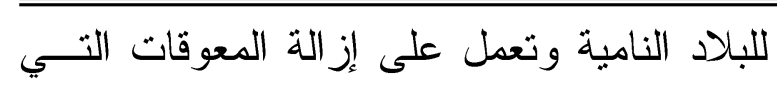
تر اكمت عبر السنين، لتقيم تتظيمات جديدة ونظم

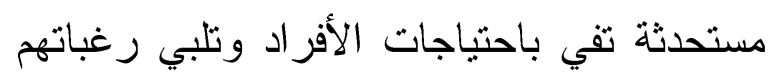

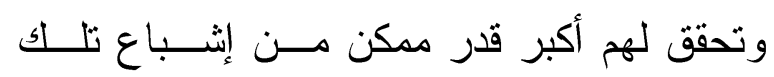

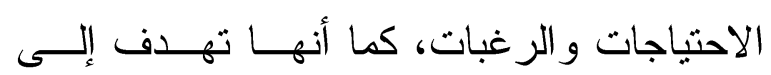

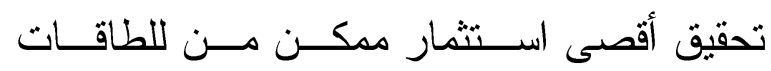

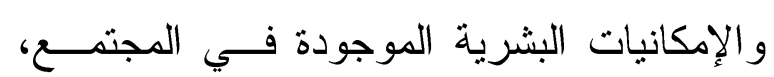
بحيث تساعد على رفع عجلة التتمية الاقتصادية

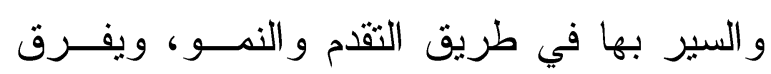

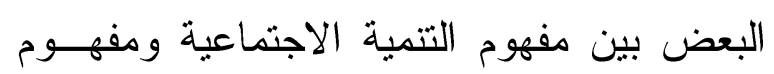

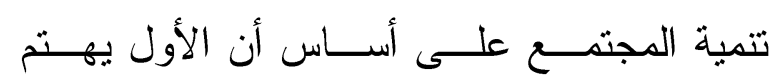

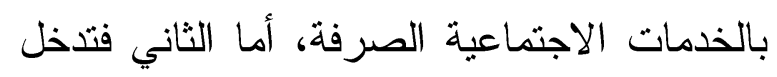

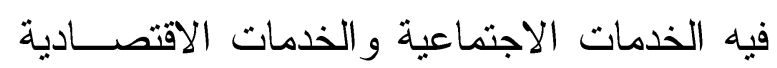
جميعاً، ويُطبق أساساً في المجتمعـات المحليــة ولئة وبعض المتخصصين، لا يفرقون بين المفهومين

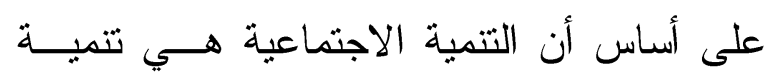

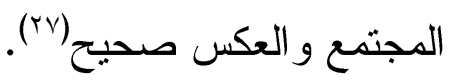

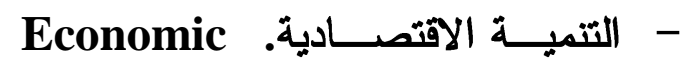

\section{Development}

يشير مفهوم التتمية الاقتصادية إلى معنى

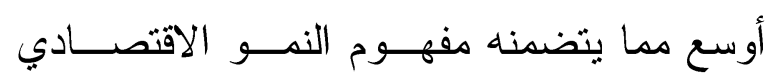

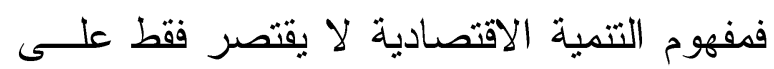

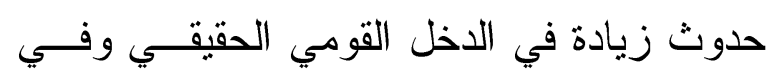
منوسط نصيب الفرد منه في المجتمع بل يتضمن إلى جانب ذلك تغيير جذري في هيكل الإنتـاج

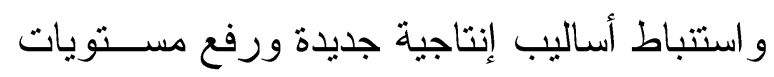

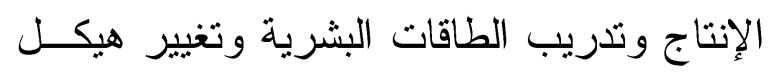

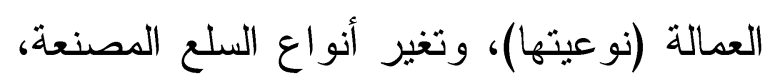

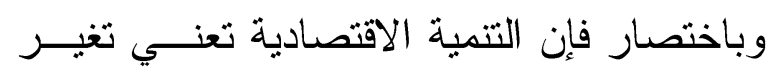

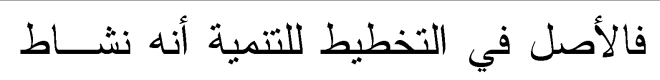

إنساني يختص بإدارة الموارد وتتميتها وذلك من فن لتهن

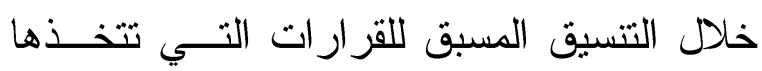

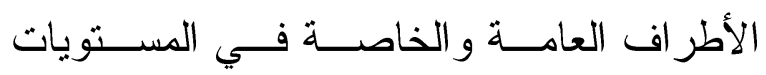

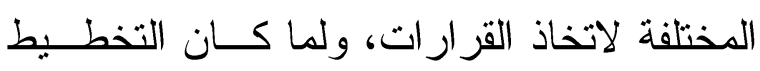

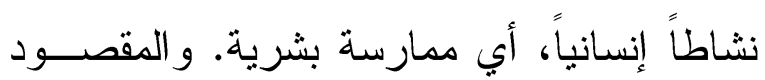
بذلك ثلاثة أمور على الأقل، أولها: أن التخطيط نشاط يستتد بالضرورة إلى العقل في إدارة شئون الإن إنهان

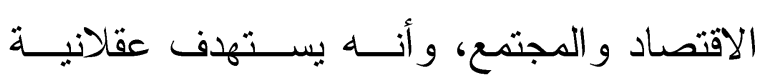

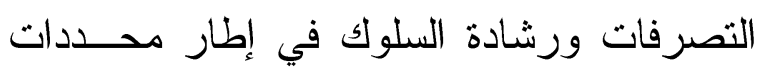

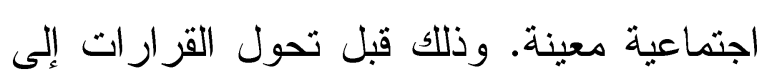

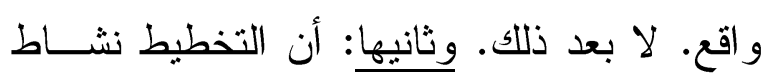

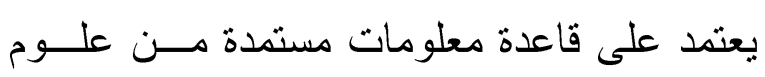

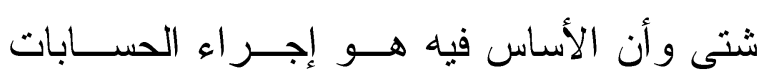
العلمية على بدائل مختلفة و المقارنة بين نتائجها، ثم اثتقاق السياسات المتو افقة مع البديل المختار

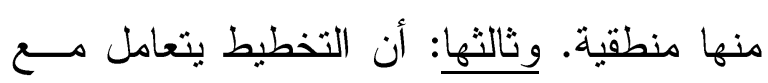
الاقتصاد أو المجتمع على أنه يُشنكل نسقاً متكاملاً تتفاعل داخله متغير ات اقتصــادية واجتماعيــة وسياسية متعددة، و هذه الطبيعة النسقية للتخطيط تلزم المخططين بالشمولية و التكامل في نظرتهر للأمور وتقييمهم لمجرياتها. و هو ما يقي عمليات

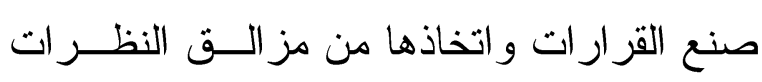
الجزئية غير المتر ابطة (؟r).

\section{مجالات التنمية.}

- التنميــــــة الاجتماعيــــــة. Social

Development

تُعد التتمية الاجتماعيــة عمليـــة تغييـــر اجتماعي نستهدف تغيير الخصائص الاجتماعية 
المتحقق ودرجة إسـهامها فيــه، حبــث تعكس التضمينية نوعاً من العدالة لكنها لا تتعلق بجانب التوزيع فقــط، و إنمــــا وبدرجة أهم، بالإسهام و المشاركة فـي العمل الإنتاجي والاقتصادي. ويمثـل توسيع دائرة الاقتصاد الرسمي، وزيادة إسهام المشرو عات الصغيرة ومتتاهيــة الصغزر وانــدماجها فــي الاقتصـــاد، وتحسين التتمية في المناطق المحرومة

$$
\text { و المهمشة ونهن). }
$$

\section{- التنميـــــة السياســـــية. Political -}

\section{Development}

إن مفهوم التتمية السياسية هـــو مفهــوم حديث و هو يعنــي تتشــئة اليــافعين و الثـــاب

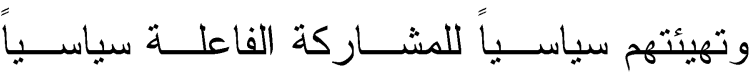
للمشـاركة الفاعلة في الحياة العامـــة، وتمكيــنـهم ليصبحوا مو اطنين مدركين لمسئولياتهم وحقوقهم وو اجباتهم، ملتزمين بالقيم الأساسية و الديمقر اطبة و المبادئ السياسية للمجتمع و الدولـــة، مـــالكين للمعارف و المهار ات الأساسية اللازمة للمشاركة الفاعلة في الحياة السياسية، ومن أجل المزاوجة بين النظرية والتطبيق في التنمية السياسية في أي مجتمع، فلابد من تو افر مقومات وشروط رئيسة أهمها: إطلاق الحريات بين جميع فئات المجتمع

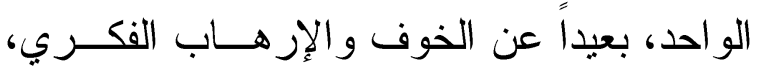
ووجود تعددية سياسية وفكريـــة ضــمن إطـــار الثو ابت، وتحقيق المساو اة في الحقوق و الو اجبات بين جميع المو اطنين، وقيام أحز اب سياسية قوية، لديها دور مؤسسات المجتمع المــدني و المــر أة
جذري في البنيان الاقتصــادي، و أيضـــاً تغيــر الهيكل الاجتماعي و التتظيمي و الثقافي للأفــر اد،

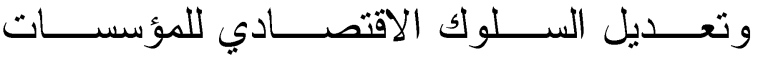
الاقتصادية، وزيادة معدل التحضر في المجتمــع وتحسن في مستويات الصحة و التعلــيم، ومسـن التفسير السابق لعملية التتمية الاقتصادية يمكنتــا أن نحدد العناصر التي تتطوي عليهــا عمليـــة

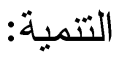

• ضرورة إحداث تغيير جذري في الهيكل

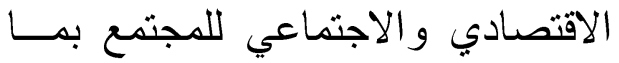
يضمن رفع الطاقة الإنتاجيــة ورقـي الكفاءة الإنتاجية مع مر اعاة (التـدر ج) في التغير طالما أن التتمية الاقتصادية مراهية عملية (طويلة الأجل وليســت عمليــة مؤقتة).

• أن محور اهتمام فــي عمليــة التتميــة

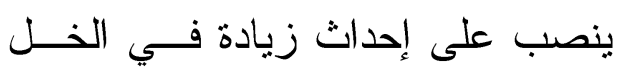
القومي الحقيقي وفي متوسط نصيب من الدخل - وليس الدخل النقدي- بهــدف إعادة توزيع الاخول بطريقة تضـــن

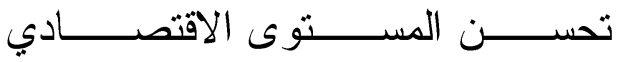
و الاجتماعي لأفر اد الطبقة الفقيرة. • حصر إمكانيات الاقتصاد القومي وتحديد أهــــداف و أولويـــات عمليـــة التتميــــة الاقتصادية (r^) • التضمنية و المشاركة الاقتصادية، ويتعلق هذا بدرجة مشاركة مختلف الفئات في النشاط الاقتصادي، ودرجة استفادة هذه الفئات من النمو و التقــدم الاقتصـــادي 
و أدى إلى مجموعة من الســلبيات فــي مجمـلـل

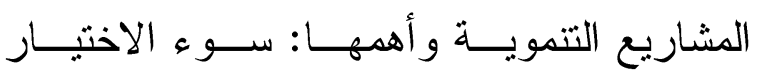

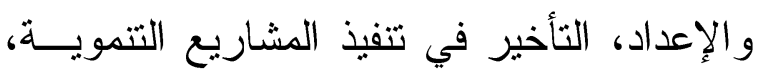
ارتفاع الكلفة، وأخيراً سوء التتفيــذ، فـالإدارة

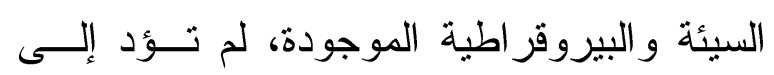

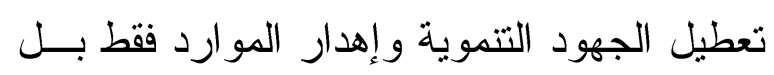

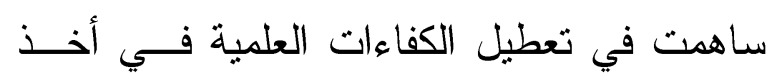

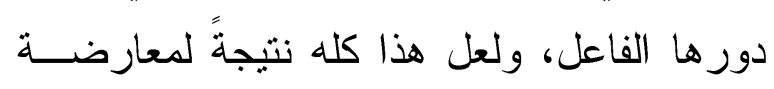

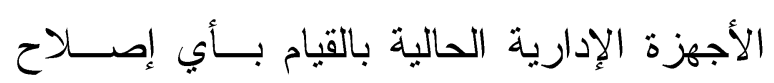
إداري يساعدها على تقليل الهدر وزيادة الكفاءة الإداء

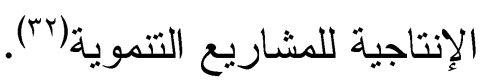

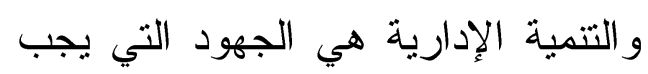

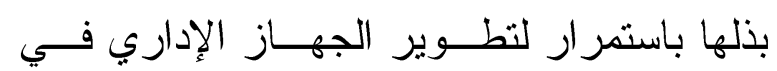
الدولة، لرفع قدراته الإدارية لتمكينه من القيــام

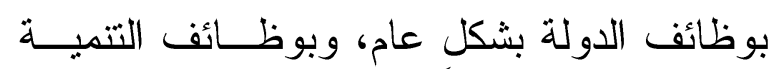
الاقتصادية و الاجتماعية و السياسية بشكل خاص، وبن وتمثل التتمية الإدارية أحسـ الأبعـاد الرئيسـية ولية

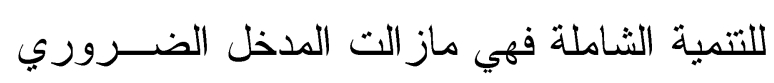

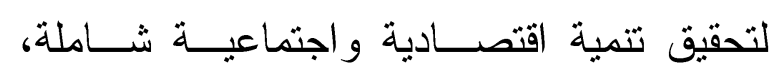

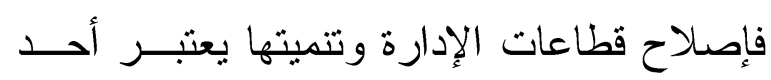

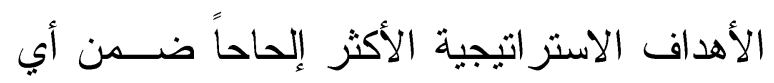

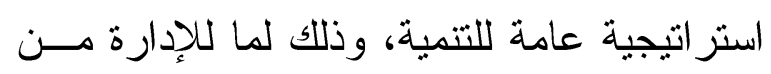

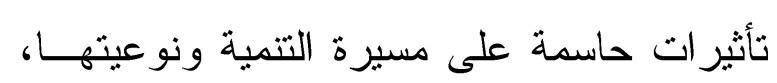

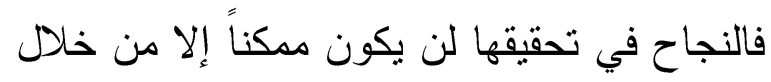

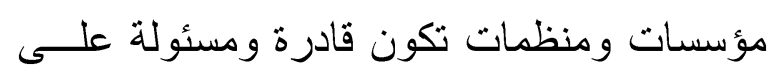

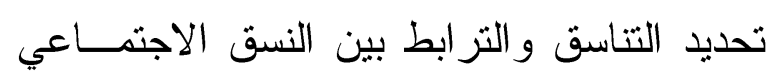

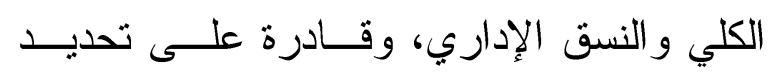
السياسات العامة وإجر اء التغير ات الضـــرورية وادية لتحقيق الأهداف المحددة من خلال طاقات العمل

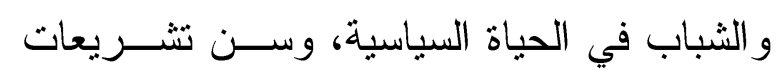
وقو انين تحمي حقوق الأفراد، ومن أجل إنجـــاح

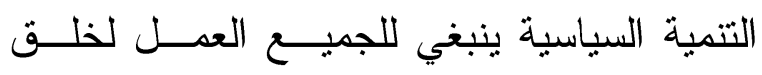

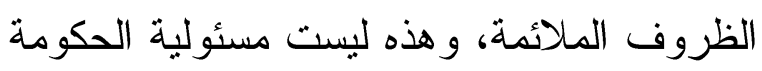
فقط بل مسئولية الجميع(·") و على ذلـــك فــإن التتميــة السياســـية بتعريفاتها المختلفة تحمل من الدفاهيم التي يجب أن تخدم بالتالي التتمية الثاملة، بمعنى أن التتمية

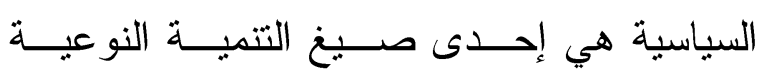
المتخصصة، وهي عملية يتم من خلالها تتميــة التها

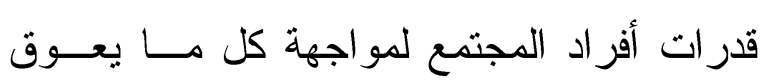
الوصول إلى مستوى أفضل. تحــرص البنيــة السياسية على التتمية الثــاملة لكافـــة شـــرائح المجتمع للعمل سوياً لمو اجهة المشكلات الداخلية

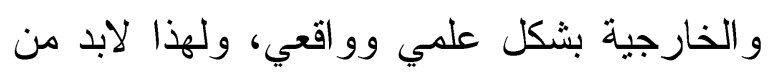

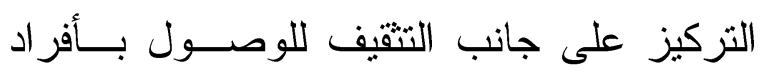

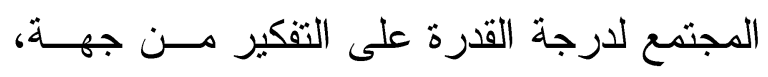

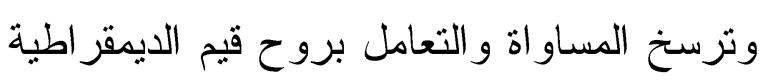

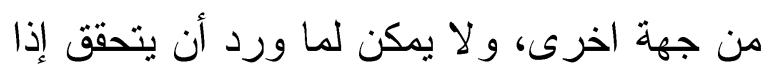

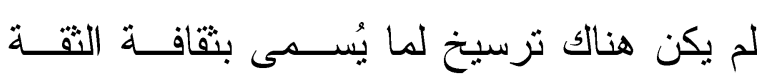

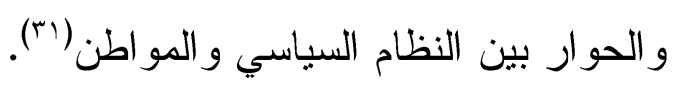

\section{- التنمية الإداريــة. Administrative}

\section{Development}

لقد أُهملت التتمية الإدارية فـــي الــوطن

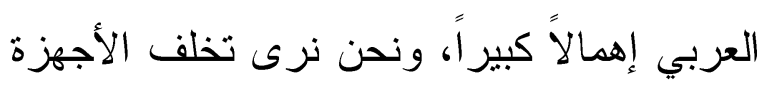

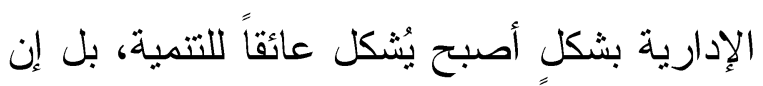

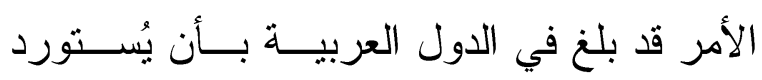

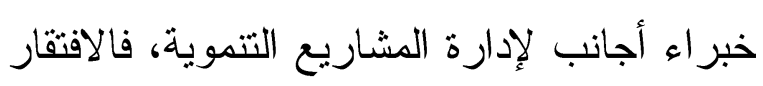
للتتمية الإدارية أثر كثيراً على التتمية الاقتصادية الإدية 
و التدريب. أم الجانب الثاني فهو يعني الاستفادة الكاملة من هذه القدر ات فيما ينفع الإنســان، أبي التئي استخدام القدرات البشرية في زيــادة الإنتـــاج، و التمتع بالفر اغ، و المشاركة في الشئون السياسية

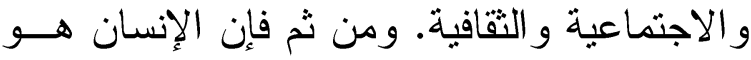
محور عملية التمية، ووسيلتها و هدفها (ب0).

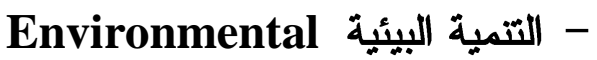
Development

تكمن العلاقة بين البيئة و التتمية، فالبيئة

هي التي تحدد شكل التنمية ومضمونها، فــي أن

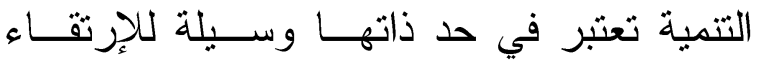
بمستوى الإنسان، فالموارد الطبيعية والبثــرية

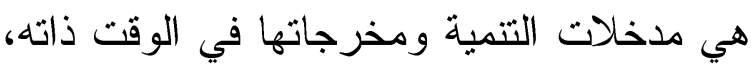

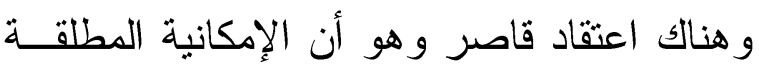

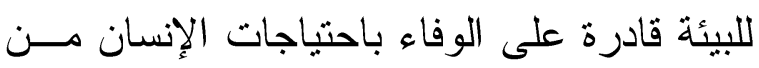

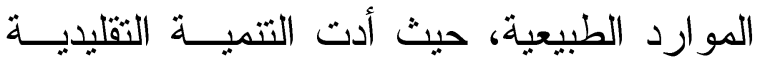

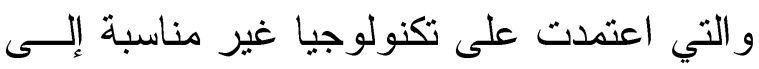
استنز اف لموارد البيئة الطبيعية، أو في العمليات

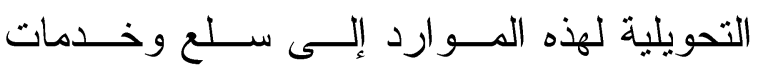
ضرورية للتنمية مما تسبب في إحداث التلــوث بأنو اعه المتعددة، فلم تلتزم هذه التتمية بمحددات

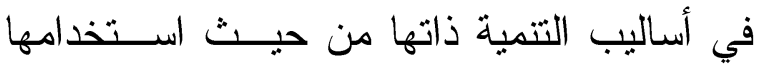

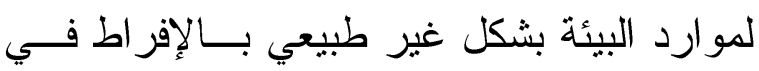

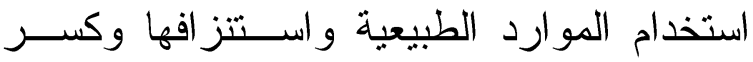
الديناميكية الطبيعية للسلاسل الغذائية المســؤلة

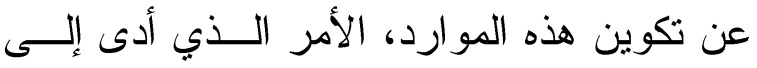

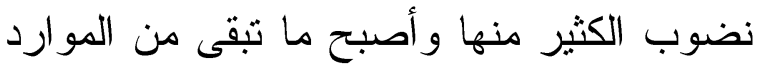

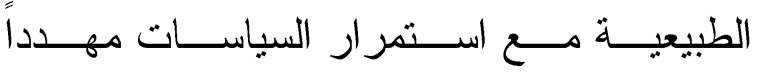
بالانتهاء (ب) (ن).
الخلاق على كل مستويات العمل الإداري، وهذا

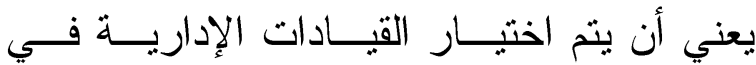

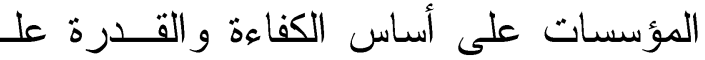
المبادرة و التظور و اكتساب مهــار ات جديــدة، وتوجيه الجهود لتحسين وتتمية قدرات الإداريين و العاملين (rr). Development

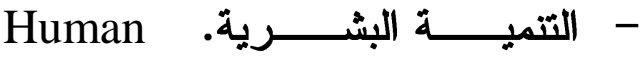
الخيار ات المتاحة أمام الأفراد، ومن حيث المبدأ هذه الخيارات بلا حدود وتتغير بمرور الوقــت،

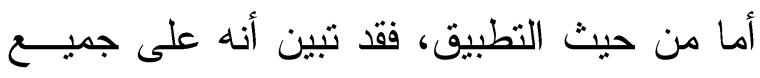
مستويات التتمية، تتركز الخيارات الأساسية في

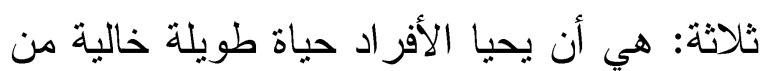

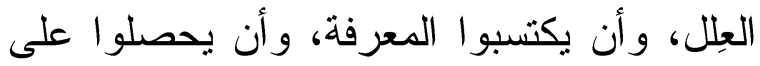
المو ارد اللازمة لتحقيق مستوى حياة كريمة، وما لم تكن هذه الخيارات الأساسية مكفولـــة، فــإن الكثير من الفرص الأخرى سيظل بعيد المنـــال،

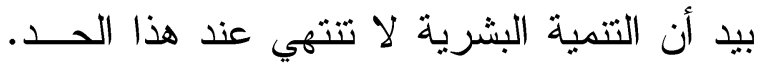

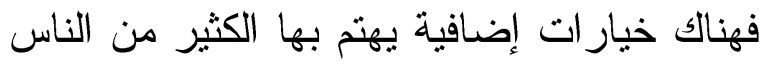

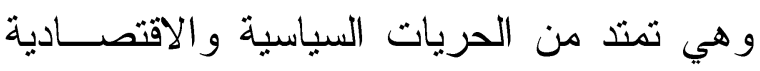

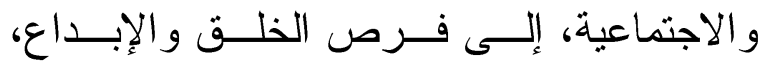

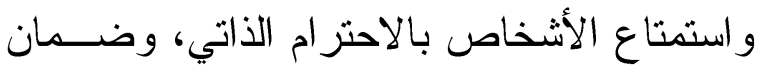
حقوق الإنسان(r). ويُلاحظ في هـــا الصــدد أن التتميــة البشرية لها جانبان هما: جانب تكوين القـدرات وجانب الاستفادة من هذه القدر ات. وفيما يتعلـق لقابق

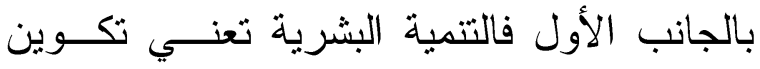
القدرات من خلا الاستثمار في التعليم والصحة 


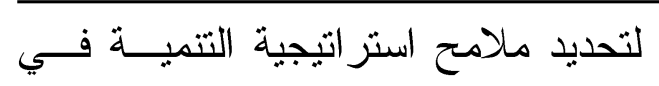

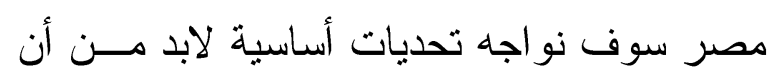
نتعامل معها، و هنا تكمن أهمية التخطيط للتنمية لوضع رؤية أفضل لمستقبل التتمية:

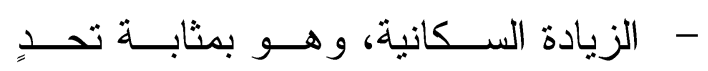

$$
\text { جو هري للدولة. }
$$

- - ضعف قاعدة الموارد الطبيعية الموجودة لمالة

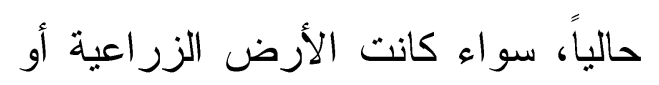

$$
\text { غير ها. }
$$

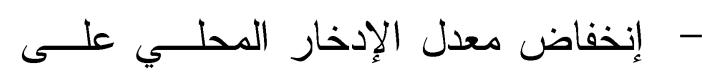
المسنوى القومي ومدى قبول الاستثمار

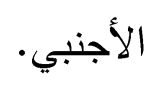

- قصور الخدمات الحكوميــة و الخــدمات

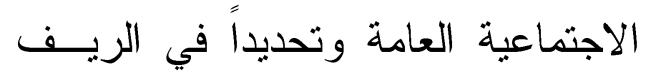

$$
\text { و الصعيد (ra). }
$$

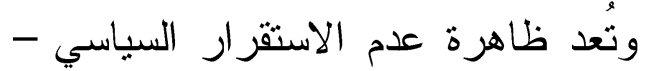

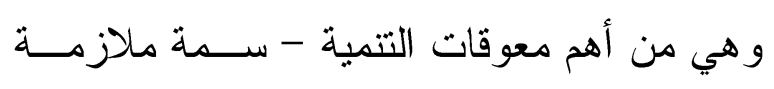
لدول العالم الثالث تقريباً، وهي تلعب دوراً كبيراً

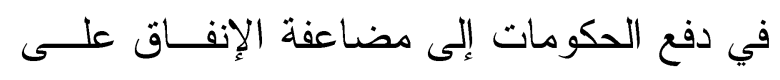

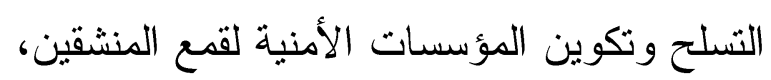

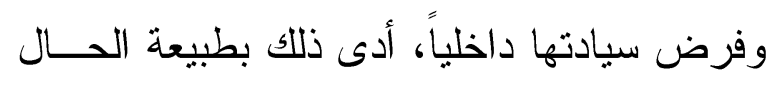

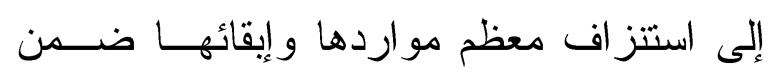

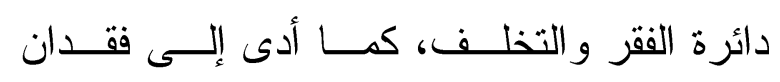

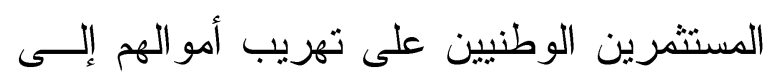

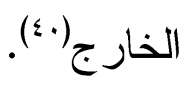

ثالثـاً: الشبـاب والتنميـة .. بـين الواقع والـرؤى

المستقبلية

يُعد الثباب عصب الأمة، وهم الثريحة

المنوط بها النهوض بالدولة وإحـــاث التتميــة

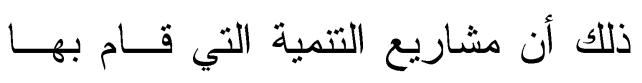

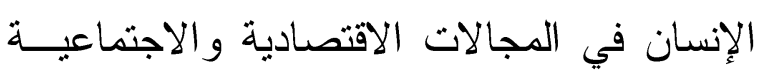

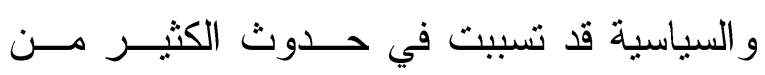

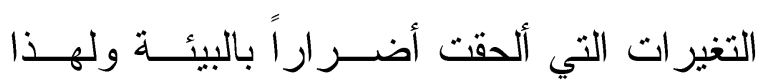
السبب داعت الأمم المتحدة إلى عقد مؤنمر للبيئة

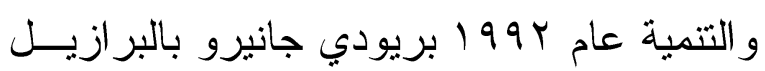

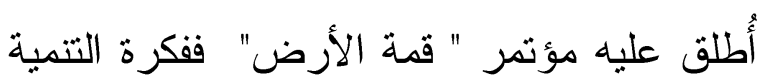
المستدامة تقوم على الرشد و الترشيد و العقلانيـــة

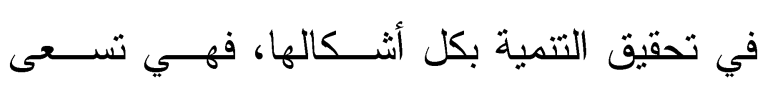

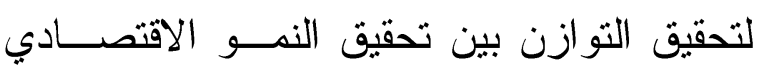

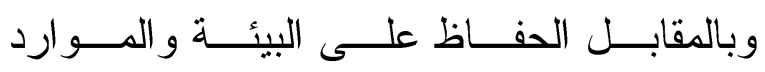

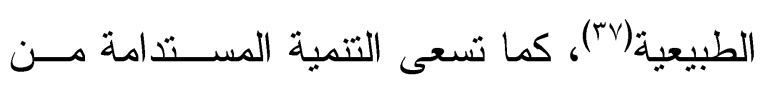

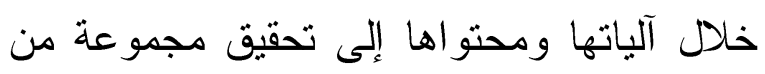
الأهداف التي يمكن تلخيصها فيما يلي: 1- تحقيق نوعية حياة أفضل للسكان. r- احتر ام البيئة الطبيعية.

ب- تعزيز وعي السكان بالمشكلات البيئ.ـــة القائمة.

ـ-تحقيق اســتخلال واســتخدام عقلانسي لـ للموارد.

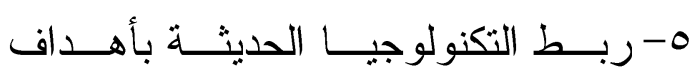

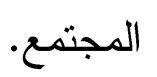
צ- إحداث تغيير مسـتمر ومناسـبـ فـي حاجات وأولويات المجتمع (م"). 
و الديمجر افية، و التعليمية، كما أن هذه المكانة قد

انبتقت وتحددت من خلال الفلسفات و التيــارات السياسية و الثقافية و أصبحت تُشكل سمة العصر، ولقد ترتب على هذه المكانة التي يمثلاها الثـــباب

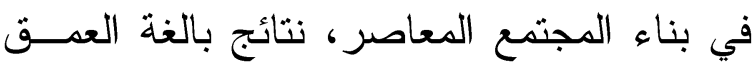

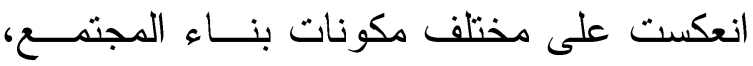
ويتأثر معدل التغير في المجتمع و إيقاعه تــأثراً مباشر اً بأوضاع الثباب في المجتمع و الوظائف المتعددة التي يؤديها الثباب في مختلف قطاعاته. ولذا تكمن أهمية الثباب بالنسبة للمجتمع فيمسا فئس يمثله الثباب من مصدر للتجديد و التغيير، فهـ لهن عادة ما يرفعون لو اء الحـديث مــن الســلوك

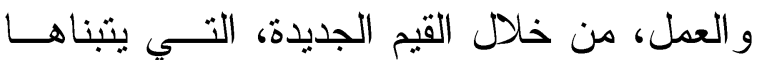

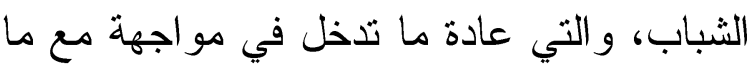

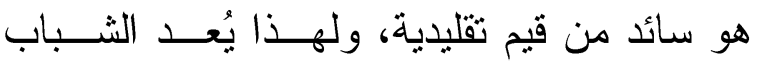

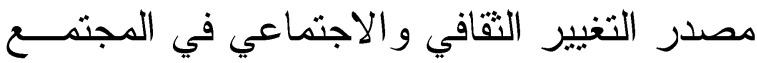

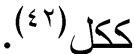

وهو ما يعني عملياً أن أولوية السياسات

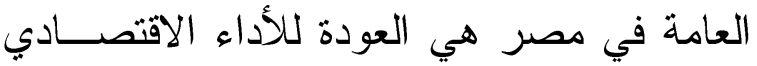

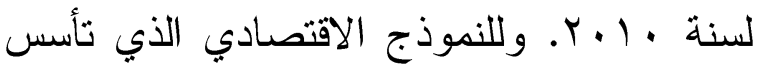
في السنوات الأخيرة من حكم مبارك، و الذي كان

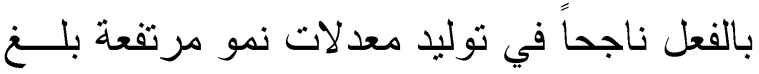

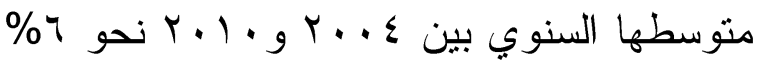

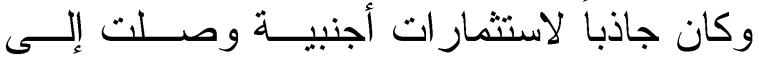
عشرة مليارات دولار قبل اندلاع الأزمة المالية

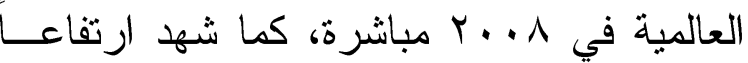
غير مسبوق في الصادرات الصـــاعية وغبــر الصناعية. ورغم الاحتفاء بما اعنبر نجاحاً على مستوى المؤشرات الكلية لذلك النـــــذج القـائم
و الابتكار و الاختر اع و الثقام. ويفترض في تلـــك الثريحة أن تكون منتجة بصورة فعالة، بمعنسى أن يمتل الثباب في هذه الشريحة القوة العاملــــة القادرة على قيادة العملية الإنتاجية في المجتمع، لإهل

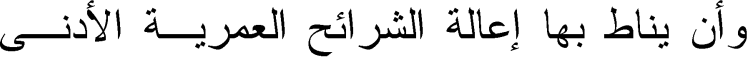
و الأعلى، و إذا كان قطاع الشباب يقع على عاتقه إنه

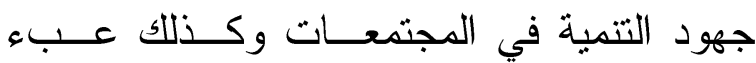
التحو لات السياسية والاجتماعية و الاقتصــادية، فعلى المستوى الو اقعي يُعد الثباب وجهين لعمة

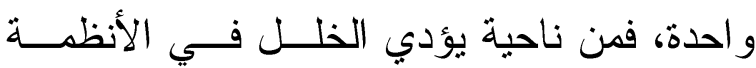

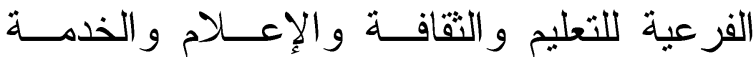

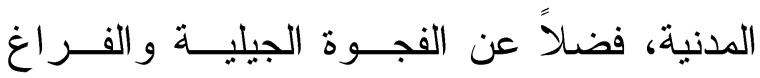
الفكري و السياسي إلى كون الثباب قوة اجتماعية

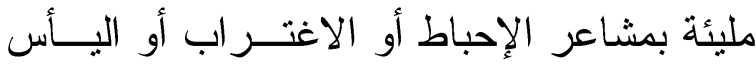
و هذه هي البيئة المنلى لثقافة العنف، ومن ناحية

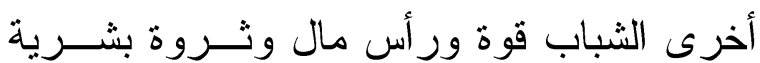
هائلة إذا أستثمر بحكمه ووعي وتخطبط علىـي واع ومستتير لطاقاتهم وترشـيدها وتوجيهـــا الاتجاه الصحيح، لتحقيق الأمل المعقود عليه في بناء مجتمع حديث(1).

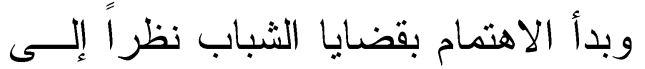

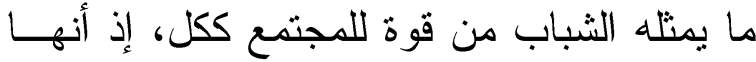

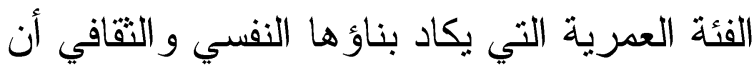

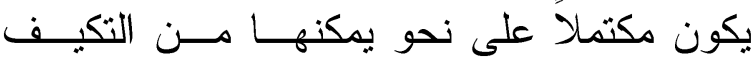
و التو افق و التفاعل، و الاندماج و المشاركة، فــي تحقيق أهداف المجتمع وتطلعاتــهـ و إنجازاتـــه. و الحقيقة أن المكانة المعاصــرة التــي يثــلها

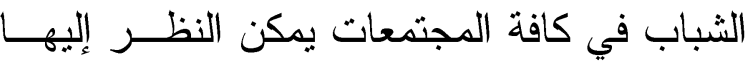
بوصفها نتاج للتغير ات الاجتماعيــة و السياســية 
مر اعياً أن يكون هناك تنسيق بين الأهداف، وأن أنسيجان

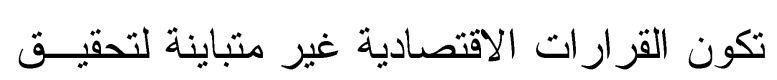

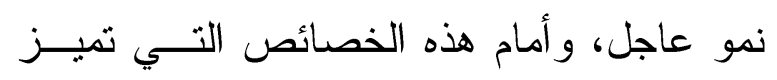

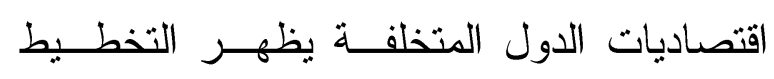

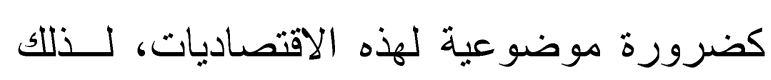

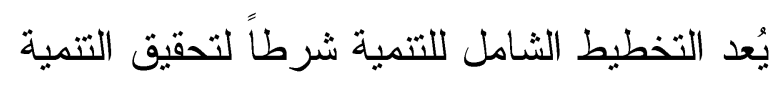

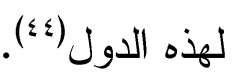

\section{رابعاً : نتائج الدراسة لأن}

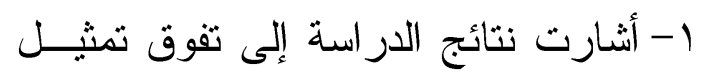

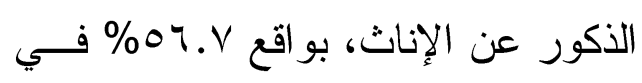

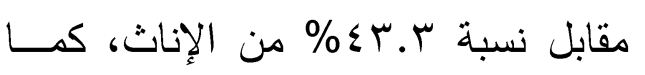

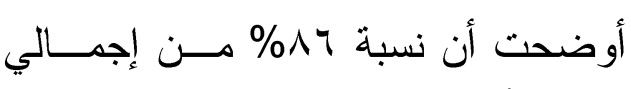

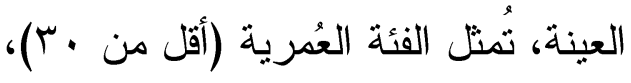

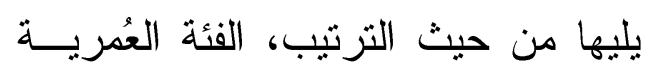

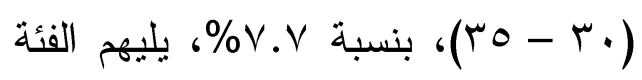

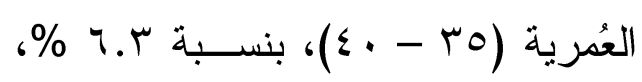

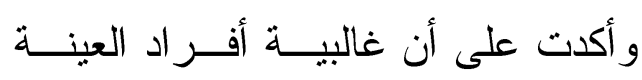

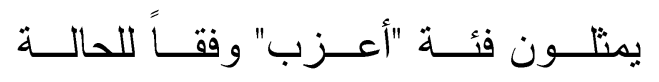

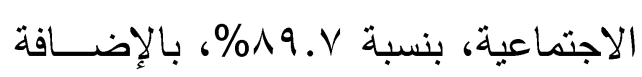

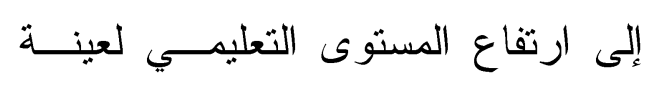
الدر اسة بنسبة ب.؟ 9\% من الحاصـلين على مؤهلٍ عالٍ و أثبتت نتائج الدراسة

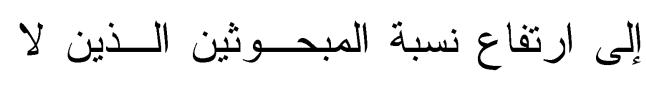
يعملون بنسبة 9.9\%\%، و هذا ما يؤكده

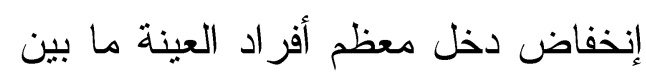

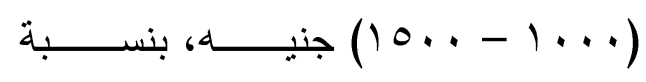

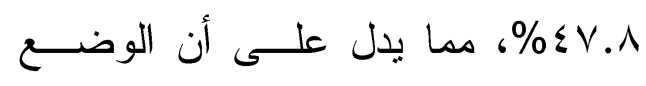

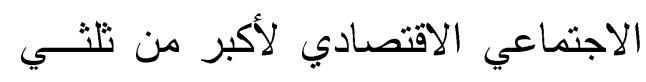
العينة بنسبة r.9. 79 متوسط.
على منطلقات نيوليبر الية إلا أنه قد أثبت، أنــهـ

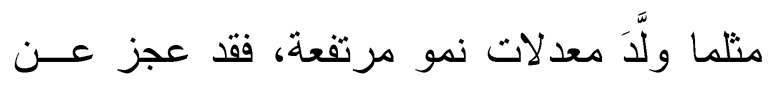

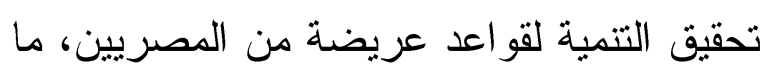

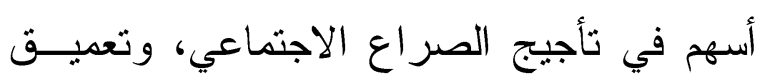

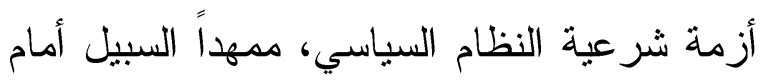

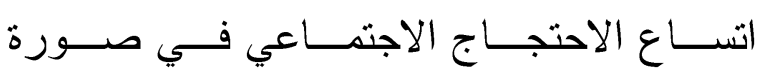

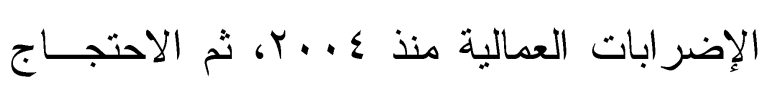

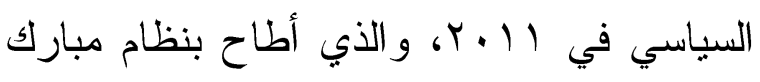

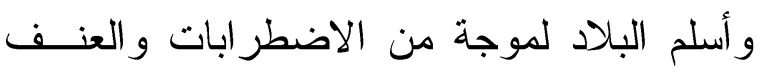

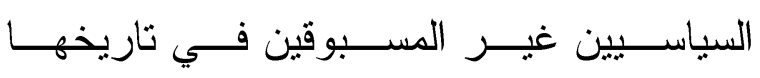
الحديث(") الحيان.

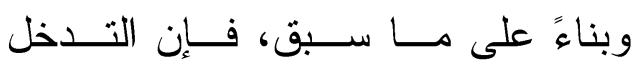
الحكومي يثير الكثير من التساؤلات في عمليـــة

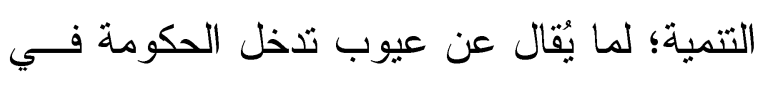

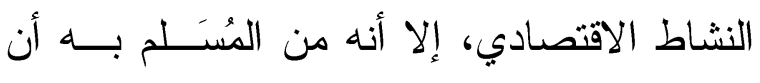

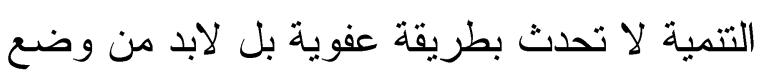

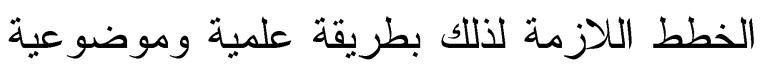

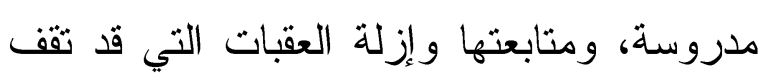

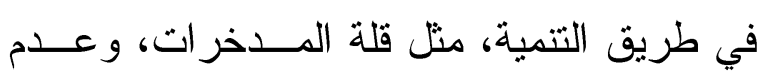

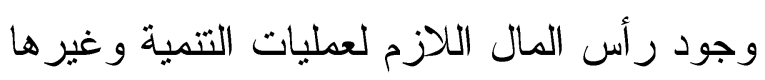

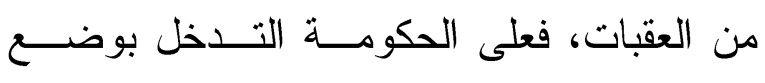

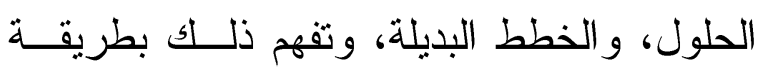

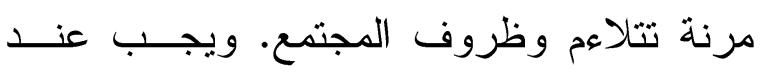

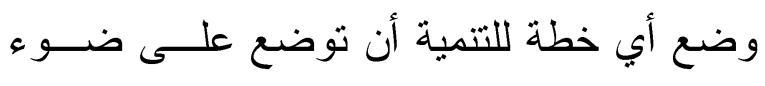

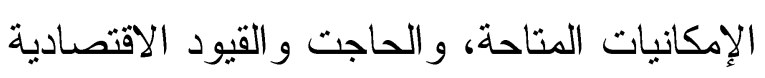

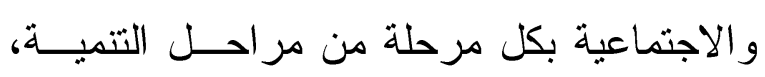

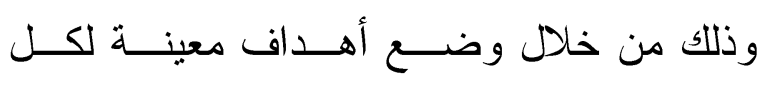

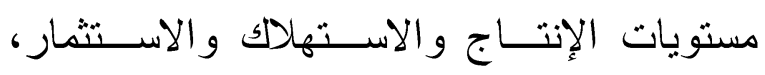

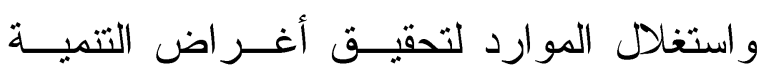


و الاستثمار ات بعد ثورتي هب يناير و •r يونيو، حيث جاء في المرتبة الأولى حل بعض المشكلات الأساسية الني يعساني

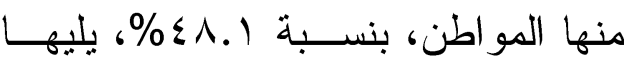
ارتفاع نسبة الاستثمار ات بشكل ملحوظ بنسبة 0.0\%\%. Y- عَبَّر أفر اد العينة عن رأيهر حول إفادة سياسة الخصخصة المجتمع و المواطن، حيث أكد غالبيــة المبحــوثين بنســبة

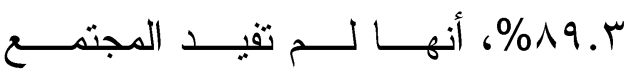
و المو اطن، مقابل مقابل V. . . 1 أفادوا بأنها أفادت المجتمع و المو اطن، ويشــير هذا إلى عدم إقتاع المبحوثين بفائدة بيع القطاع العام وخصخصنه، بل يؤكد ذلك

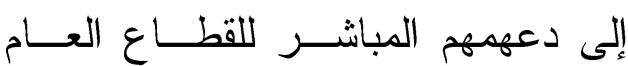
وتتميته بما يو اكب متطلبــات العصــر و أساليب التنمية الحديثة. -V توصلت الدراسة إلى أسباب تعثز جهود

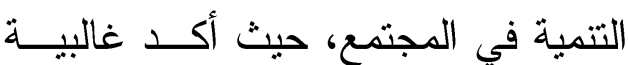

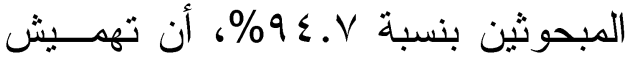
الشباب و عدم إثـــر اكهم فــي عمليــات التتمية، من أهم الأسباب، يليها غيــاب

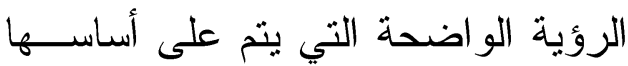

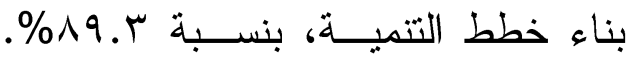
أيضاً توجيه الاستثمار ات الأجنبية فــي مصر تجاه القطاع الخدمي أولاً ثم قطاع

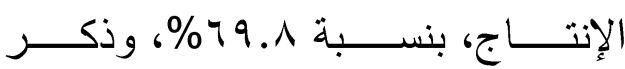
المبحوثون أن الفساد الإداري في مختلف القطاعات يمثل نسبة 9.9.9، و وعـدم
Y- أكدت نتائج الدراسة علــى أن مشــلة البطالة من أهم المشكلات المؤثرة على الثباب باعتبار هم أكثر الفئـات التـي تحتاج للعمل وبناء حياتهم، يترثب عليها مشكلة الفقر، أيضاً انعدام الأمن و انتشار البلطجة، وفي ظل هذه النتائج أكد غالبية أفراد العينة بأن جميع المشكلات السابقة تؤثر وبشكل كبير على الثباب بنســبة 7. 9\%\%، مما يشير إلى أنهـــا تعـوق وبشكل كبير الشــباب وتحـــ مــن أداء مهامهم في تتمية المجتمع علــى أكمـلـل وجه. ب-بينت الدراسة أن أهم التحــديات التـي

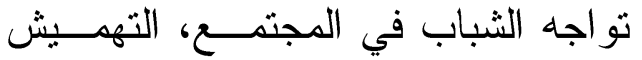

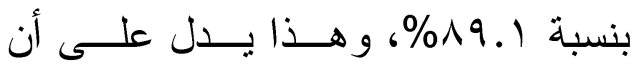
الشباب يشعرون بعــدم أدائهــم الــدور

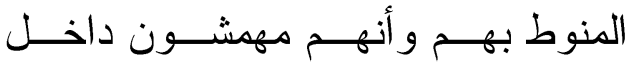
المجتمع، يلي تلك التحــديات البطالـــة وســـوء الوضـــع الاقتصـــادي بنســـبة

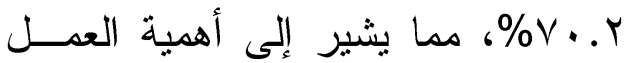
بالنسبة للشباب، يلهم الفساد، و أخير اً عدم الهم

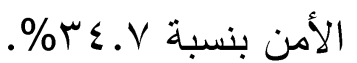
ع- أبدى أفر اد عينة البحث رأيهم بعدم إفادة تشجيع الاقتصـاد الحُــر والاســتشمار ات

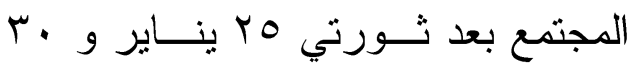

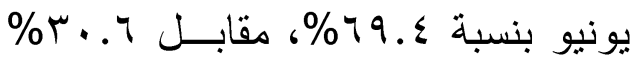

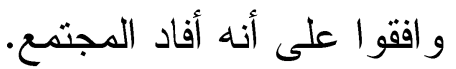
- أكدت الدراسة أن هناك العديد من النتائج المترثبة على تشجيع الاقتصــاد الحُـر 
الدولة ومو اقع اتخاذ القرار فليس له دور

1 1أكدت الدر اســـة علــى أن هنــاك دور

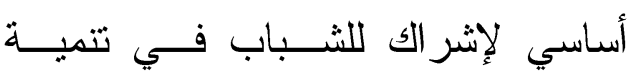
المجتمع المصري، حيث جاء في المرتبة

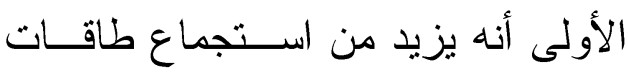

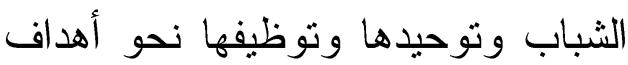

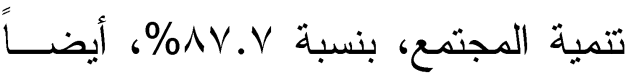

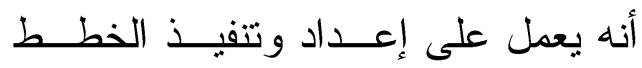

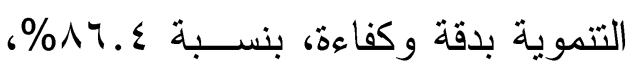
بالإضـافة إلى أنه يســاهم فــي زيــادة بلها

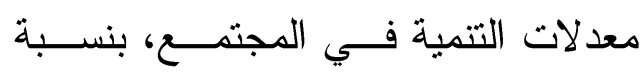

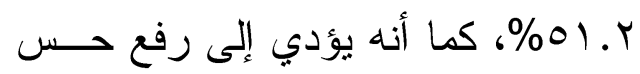
المسؤولية و الانضباط لدى الثباب مـن لهن خلال عملية اتخاذ القرارات المصيرية،

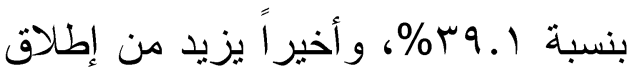

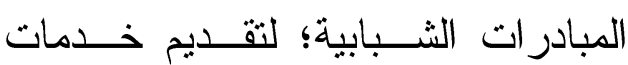
طوعية تساهم في تقدم المجتمع وحسل مشكلاته، بنسبة r. • r\%\%.

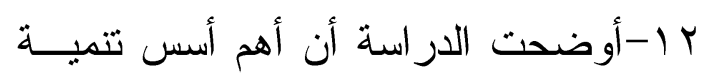

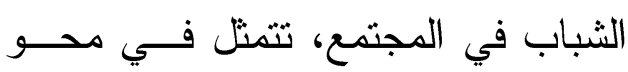
أميتهم وتعليمهر، تأسيسهم وتتميتهم فكرياً

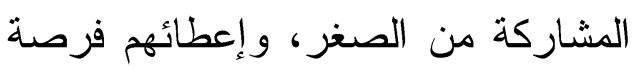
للعمل في المحليات وتحمل المســـولية، بالإضـافة إلى تفعيـل كوتــة الثــباب لتمكينهم من المشاركة فــي انتخابـات الفيات المحليات و المجالس النيابية المختلفة. با ا-أثثتت الدراسة أن أسس تتمية للثـــباب

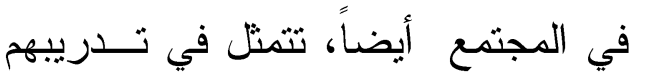

الاستفادة المُلى من رأس المال البثــري

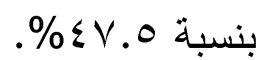

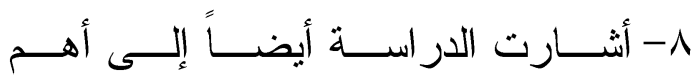

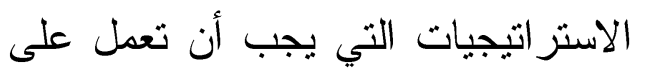

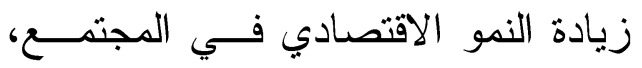

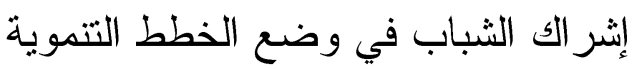

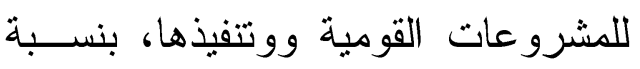

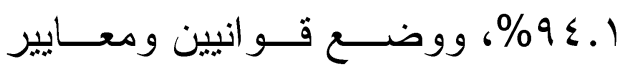
أساسية لاختيار نسبة معينة من الثــباب

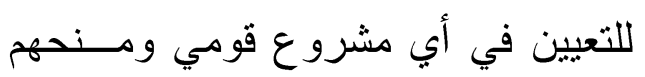

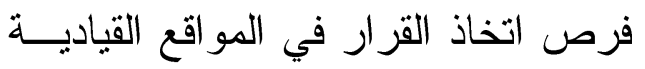

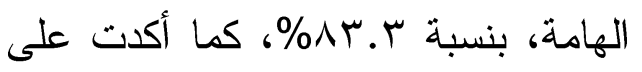
تفعيل دور الرقابة الإدارية على مختلف

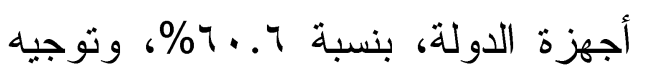

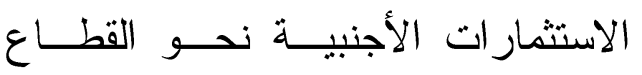
الإنتاجي العيني بدلاً من الخدمي، بنسبة الإنة \% \%^.

9- كما أكد أفراد العينة على أهمية إعـادة

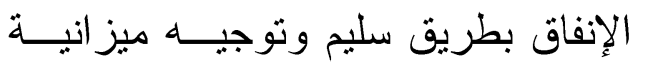
الدولة في اتجاه تنموي، ومعالجة سلبيات الإدارة على مستوى الدولة لوضع حلول

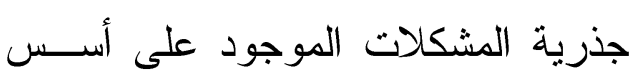
وقو اعد علمية مدروسة.

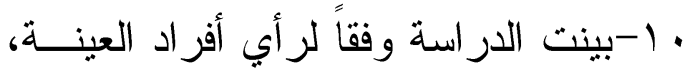

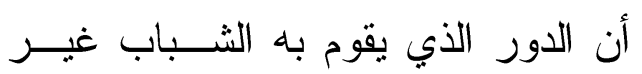

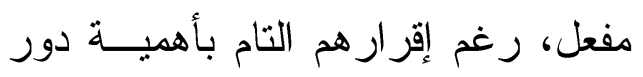

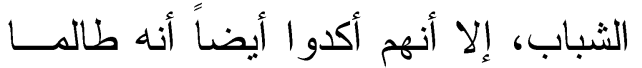
الثباب بعد عن الششــاركة فــي إدارة إلهاب 
مقتزحات اللدراسة

- عمل دورات تدريبية للشباب الخريجين

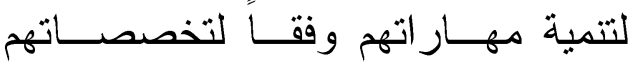

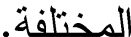

- وضع قانون بتخصيص نسـبة محسـددة للشباب للتعيين في المشروعات القومية. - عمل حوار مجتمعسي حـول القضــايا القومية التتموية و إنشر الك الثــباب فــي وضع الخطط التنفيذية لها. - تشجيع الثباب على تتفيذ المشـروعات

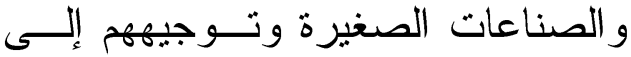

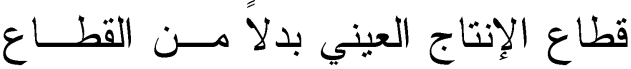

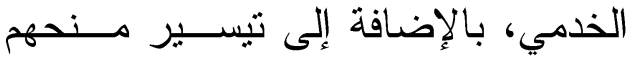

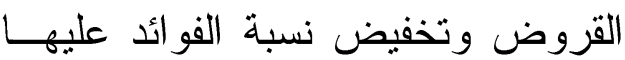

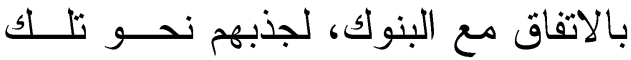

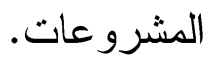

\section{المراجع}

(1) جوناثان تيرنر، بناء نظرية علم الاجتماع،

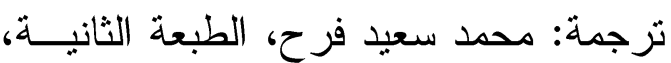

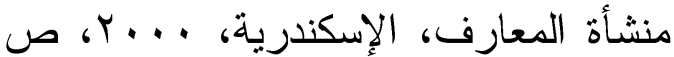
.410

() سامية حسن الساعاتي، الثقافة و الثخصــية حوار لا ينتهي، الهيئة المصــرية العامــة

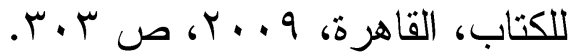
جوناثان تيرنز، مرجع سابق، ص • •r. بشيري فــايزة وبوترعـة بـاتول، دور الخدمات الاستشارية في تحسين كفاءة رأس المال البشري (دراســة ميدانيــة بمجمــعـ صيدال فرع فرمــال قســنطينة)، رســالة
على اتخاذ القرار وتأهيل الكو ادر مـنـهم

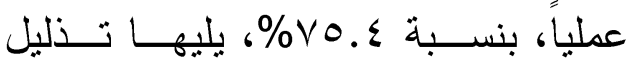
العقبات أمام الثباب وعـدّهم كعنصــر فاعل في التغيير داخل المجتمع، بنســبة

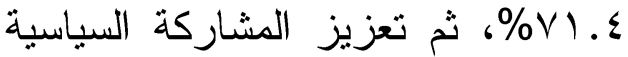
الفاعلة للشباب في الانتخابات المختلفة،

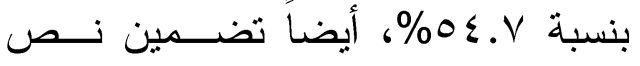
دستوري يؤكد على تمكين الثباب مــن

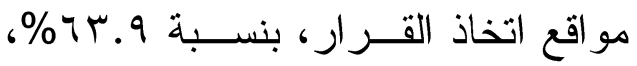
يليها عمل ورش عمل وندوات تثقيفيـة لتتمية الوعي لــدى الثـــباب، بنســـة

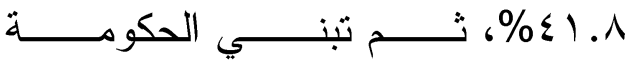

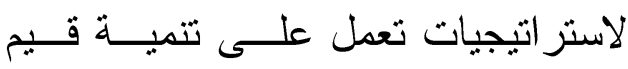
الانتماء و المواطنة لدى الثباب، بنســـة

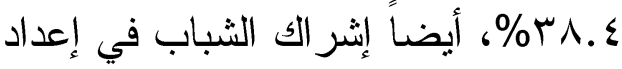

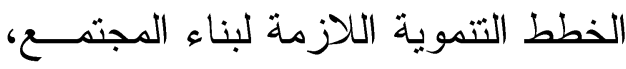

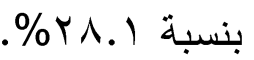
ع ا-أوضحت الدراسة أن هناك تأثير كبيــر لدور الثباب في تتمية المجتمع، واستفادة

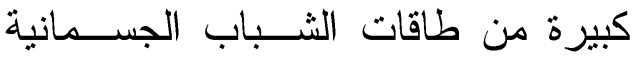

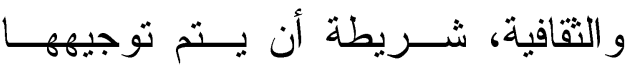

$$
\text { التوجيه الصحيح. }
$$

10-أكدت الدراسة على أهمية تدعيم الثباب

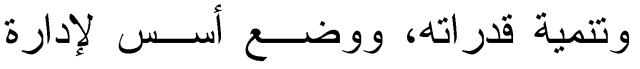
طاقاته، من أجل الاستفادة منهم في تتمية 
(1)(علي غربي وآخرون، تتمية المجتمع مسن

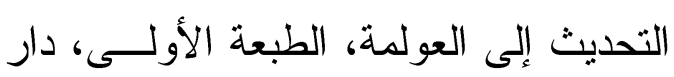

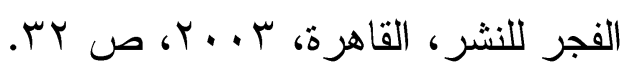
(Y ( ) أحمد زايد، التقافة كمدخل للتنمية الثــاملة،

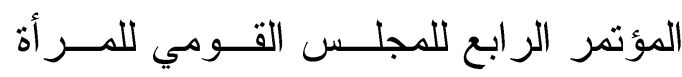

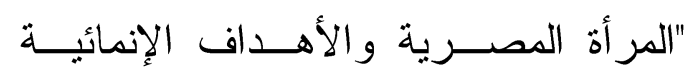

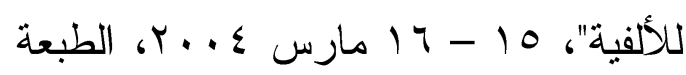
الأولى، مطابع الثرطة للنشر، الإسكندرية،

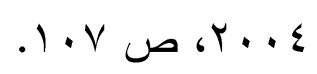

(r) (I عبد الله بن سعيد بن محمد آل عبود، قـيم المو اطنة لدى الشباب و إسهامها في تعزيز

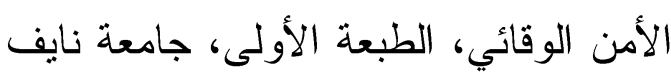

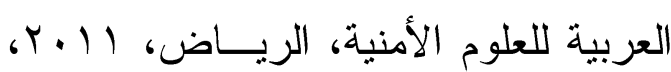

$$
\text { ص IVI }
$$

(ع () علي ليلة، الثباب في عالم متغير : تأملات

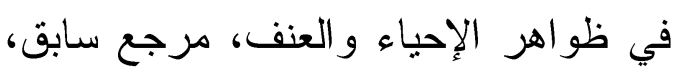

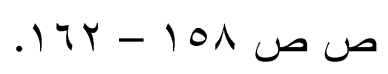

(10)نهى إبــر اهيم ســلامه إبــر اهيم، التفــق

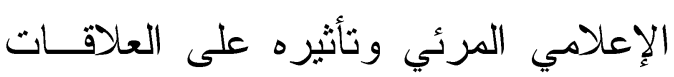
الاجتماعية للشباب "در اسة سوسـيـيولوجية الإية

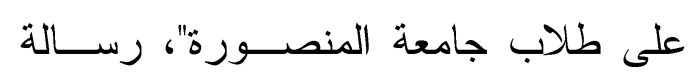

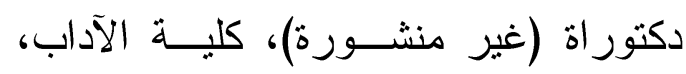

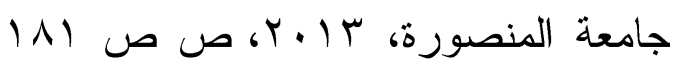

$$
\text { . INr- }
$$

(7 (1)ناجية مصطفى عمسارة صـالح، تــأثثر

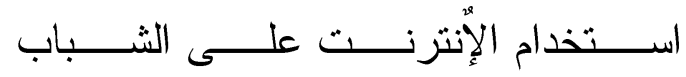
الجامعي"در اسة ميدانية على طلاب جامعة الأترنة

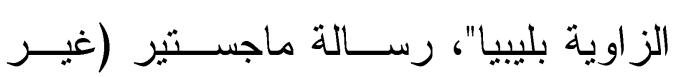

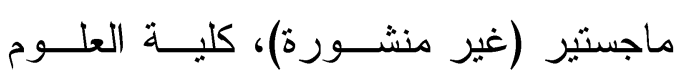

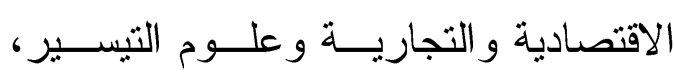

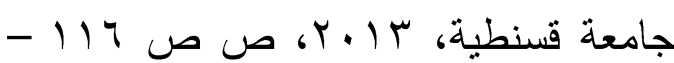
$.11 \mathrm{~V}$

محمد مصطفى محمود، الاستثمار في رأس

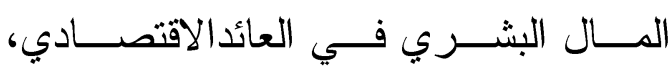

$$
\text { 11 }
$$

http://www.hrdiscussion.com/attachment.ph $\mathrm{p}$ ?attachmentid $=5512 \& \mathrm{~d}=1283986421$

(6) Gene Pease and others, Human Capital Analytics 'How to Harness the Potential of your Organization's Greatest Asset', John Wiley \& Sons Inc., Hoboken, New Jersey, 2013, P. 28.

أعضاء هيئة التّريس قسم الاجتماع كليـــة

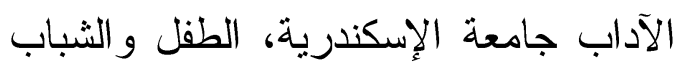

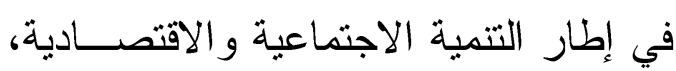

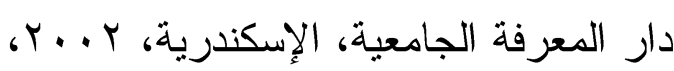
ص ص

(^) هدى عبد الجليل يوسـف بــاطن، تـأثير

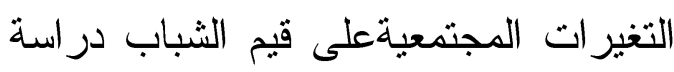

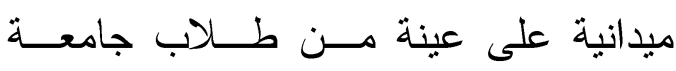
المنصورة، رسالة دكتور اة (غير منشورة)،

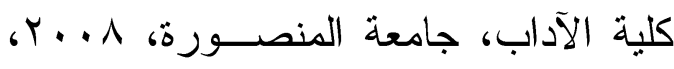

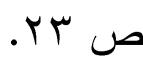
محمد عاطف غيث ومحمد علـي محمـد، لآل

دراسات في التنمية و التخطيط الاجتماعي،

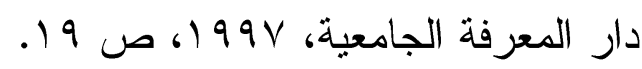

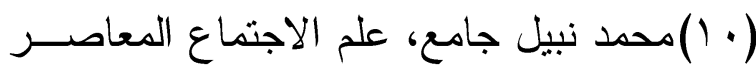
ووصايا التتمية، دار الجامعــة الجديــدة،

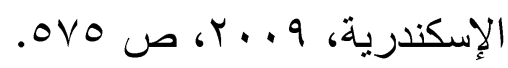


تزجمة: مصطفى قاسم، الطبعـــة الأولـىى،

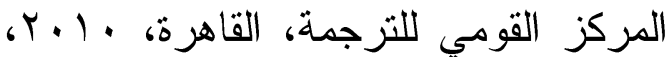

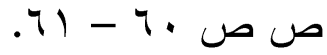

(24) Magda Kandil, Human Capital in Egypt, The Road to Sustainable Development, 1st edition, The American University in Cairo, Cairo, 2013, P. 5.

(25) Jules N. Pretty and Ian Scoones, Institutionalizing Adaptive Planning and Local Level Concerns: Looking to the Future, chapter in: Nici Nelson and others, Power and Participatory Development Theory and Practice, Intermediate Technology Publications, London, 1995, P. 159.

(YT) إبر اهيم العيسوي، التخطيط للتنمية و التغير

الاجتماعي في مصر خلال نصف قـرن:

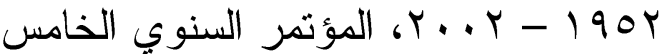

"التغير الاجتماعي في المجتمع المصــري

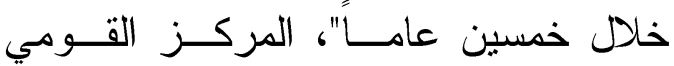

للبحوث الاجتماعية و الجنائيــة، · ب - سب

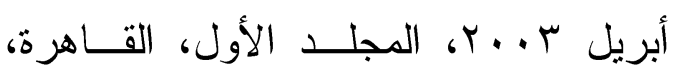

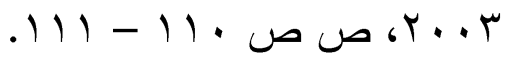

محمد الشربيني جبر محمــد داود، تحليـلـ (YV)

سوسيولوجي لدور ديمقر اطية الصفوة فـي

تحقيق أهداف التنمية و التحــديث در اســـة

مبدانية على أعضــاء المجلـس الثـــــي المحلي بمدينة المنصورة، رسالة ماجستير

(غير منشــورة)، كليــة الآداب، جامعـــة

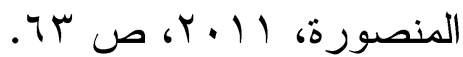

هشام محمود الأقداحي، مشكلات التنميــة

و التخطـ يط فـــي التجمعــــات الجديــــدة
منشورة)، كلية الآداب، جامعة المنصورة،

$$
\begin{aligned}
& 90-9 \leq 0 \\
& \text { (المرجع السابق، ص (IV) }
\end{aligned}
$$

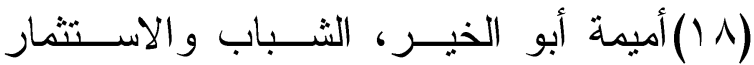

الاجتماعي: در اسة حالة على عينــة مــن

مديري مؤسسات المجتمع المدني، المؤتمر

السنوي الثالث عشر"الاستثمار الاجتمــــي

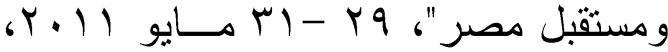

المركــز القــومي للبحــــوث الاجتماعيـــة

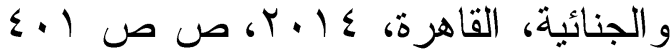

$$
\text { . } \varepsilon \cdot r-
$$

(9 ()ثقافة الشباب المصري، مركز الدراســات

المستقبلية بمركز المعلومات ودعم اتخــاذ

القرار، قضايا مستقبلية، العدد ب، القاهرة،

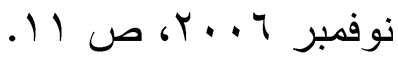

(Y. ) خالا محمد الزواوي، البطالة فــي الــوطن

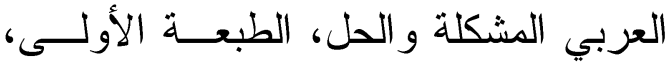

مجموعة النيل العربية للنشــر، القــاهرة،

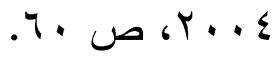

(Yl)

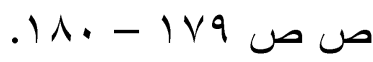

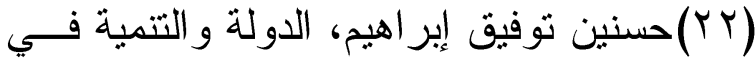

مصر : الجوانــب و المتغيـر ات السياســية

(در اسة مــن منظــــور مقــارن)، مركــز

در استات وبحوث الــدول الناميــة، كليــة

الاقتصاد و العلوم السياسية، جامعة القاهرة،

$$
\text { . } Y \leqslant V-Y \leqslant T \text { ص ص ص... }
$$

(YT) نادية رمسيس فر ح، الاقتصــاد السياســي

لمصر دور علاقات القــوة فــي التتميـــة، 
عابد الجابري و آخرون، التتمية البشرية في

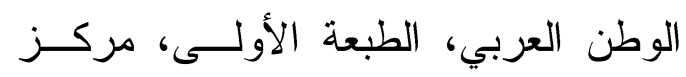

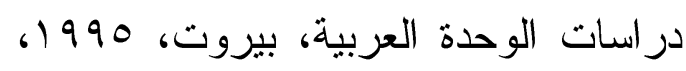

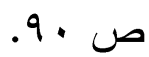

(ب) عبد القادر محمــد عبـــد القــادر عطيــة، اتجاهات حديثة في التتمبة، الدار الجامعية للنشر، الإسكندرية، 999 (، ص 9 9؛. (ד/r)محمود محمد محمود و أحمد عبــد الفتــاح ناجي، التتمية في ظل عالم متغير، مكتبــة زهر اء الشرق، القاهرة، V. . . Y، صسبـ. مختار رحاب، العلوم الاجتماعية و التتميــة (rV)

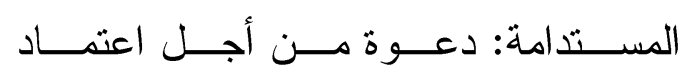

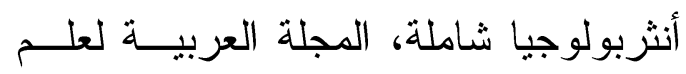
الاجتماع، التنمية البشرية ومجتمع المعرفة، كلية الآداب، جامعة القاهرة، مركز البحوث و الدراسات الاجتماعية، العدد الثامن، يوليه .1 .9 ص. 111

(ץ^) عثمان محمد غنيم وماجدة أبو زنط، التتمية

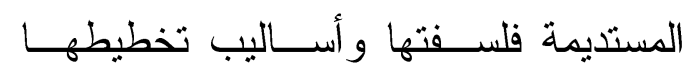
وأدوات قياسها، الطبعة الأولى، دار صفاء

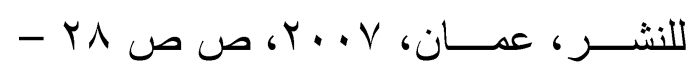
r.

(q ץ) عبد الفتاح الجبــالي، مقومــات ومحــاور التمية المستقبلية في مصر، في: مصطفى أحمد مصطفى ومحمود عبد الحي صلاح، تتمية مصر "رؤية مستقبلية"، أعمال ندوات ومدئ معهد التخطيط القومي، القــاهرة، يوليــو ليه

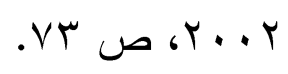

و المستحدثة، مؤسســـة شــباب الجامعــة،

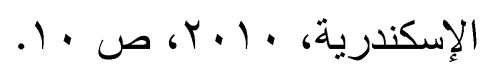

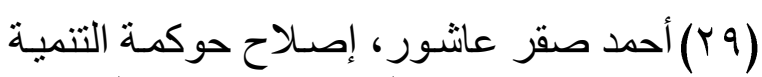

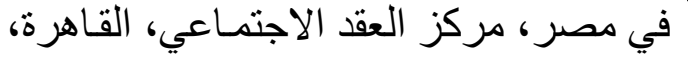

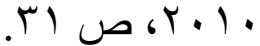

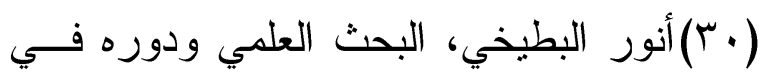
التتمية، فصل في: إسماعيل سراج الــدين و آخرون، أسس التحديث و التنمبة العربيـــة في زمن العولمة، الطبعة الأولى، مؤسســـة

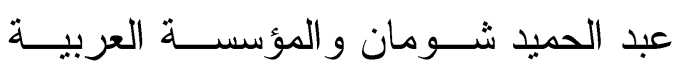

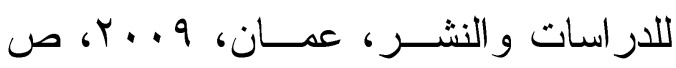
.

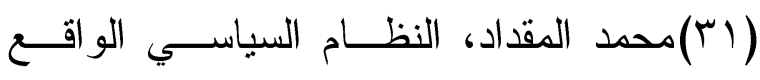
والإصلاحات المطلوبة، فصل في: شملان العيسى و آخرون، الإصلاحات السياسية في العالم العربي، أوراق عمل ووثائق النــدوة

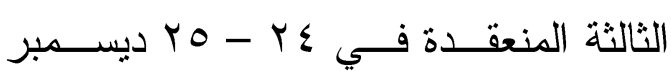
ع . . Y، سلســــة النـــدوات الاســـتر اتيجية و المستقبلية، مركز الدراسات الاستر اتيجية و المستقبلية، جامعة الكويت، العـدد الأول، كردك،

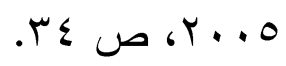

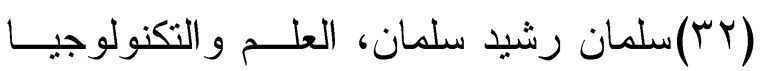
و التتمية البديلة، الطبعة الأولى، دار الطليعة

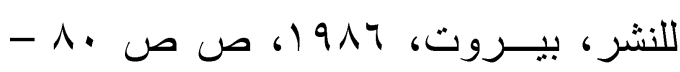
.$\wedge 1$

(بسم)محمد منير حجــاب، الإعـــلام والتتميـــة

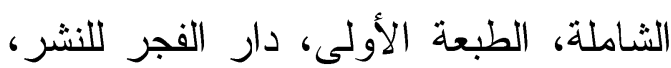
القاهرة، 9919 1، ص ص 97 - . (عץ)جورج القصيفي، التنمية البشرية: مراجعة نقدية للمفهوم و المضمون، فصل في: محمد 


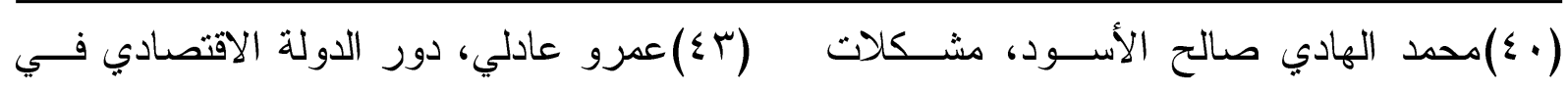

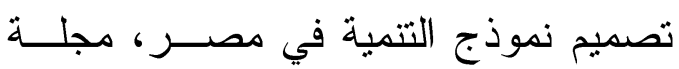

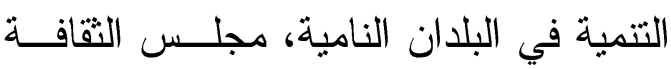

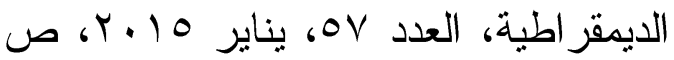

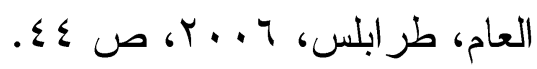

.91

( (2) نهى إبر اهيم سلامه إبر اهيم، مرجع سابق،

ا ـ هشام مصــطفى الجمـل، دور الــــوارد

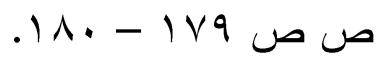

البشرية في تمويل التتمية بين النظام المالي

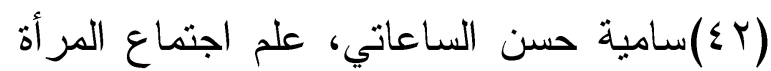

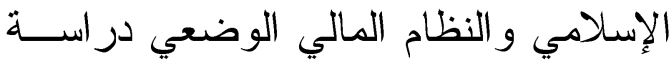

رؤية معاصرة لأهـــ قضــاياها، الهيئــة

مقارنة، دار الفكر الجامعي، الإســكندرية،

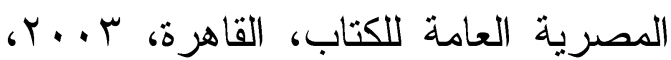

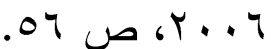

ص 